\title{
AMAGADA, PERSEGUIDA Y ¿SOMETIDA? \\ DISCURSO SATÍRICO-VISUAL Y NORMATIVA \\ LEGAL SOBRE LA LIBERTAD DE IMPRENTA. \\ CIUDAD DE MÉXICO, 1868-1883
}

Fausta Gantús

Instituto de Investigaciones Dr. José María Luis Mora

$\mathrm{E}_{\text {México aproximadamente } 46 \text { títulos de periódicos con cari- }}^{\text {ntre } 1868 \text { y } 1883 \text { circularon por las calles de la ciudad de }}$ caturas. Y decimos aproximado porque, como es sabido, resulta imposible tener una cifra exacta debido a que muchos se perdieron, y sólo sabemos de la existencia de algunos de ellos por alusiones hechas en otros impresos. ${ }^{1}$ De esos 46 títulos hubo algunos que se repitieron, pues se trata de periódicos que se publicaron en diferentes momentos manteniendo el mismo nombre pero cambiando de época, tal es el caso con dos de La Carabina de Ambrosio (1875-1876 y 1876) y Mefistófeles (1877-1878 y 1878); La Orquesta también vio dos épocas en este periodo, pero correspondientes a la tercera (1867-1875) y la cuarta (1877); ${ }^{2}$ y El

Fecha de recepción: 30 de julio de 2018

Fecha de aceptación: 2 de septiembre de 2018

\footnotetext{
1 Agradezco la asistencia en la investigación de David Cabral y Gerardo Ramírez, así como las lecturas de los integrantes del Seminario-Taller: Libertad de imprenta en el México del siglo xIx, realizado en el Instituto Mora en 2017. El recuento es nuestro. En esta cifra sólo se incluyen aquellos de cuya existencia queda algún rastro.

2 La primera época se publicó de 1861 a 1863 y la segunda de 1864 a 1866.
} 
Padre Cobos tuvo cinco (1869, 1871, 1873-1876 y 1880), aunque la cuarta no la hemos podido localizar (pero tuvo que haberse publicado entre 1877 y 1879).

En lo que toca a duración la más longeva fue La Orquesta, en su tercera época, que alcanzó los 8 años de vida; le siguen $E l$ Abuizote y El Padre Cobos, también en su tercera época, que casi llegaron a los tres años. Y con cerca de dos años se encuentran El Boquiflojo, La Casera, Don Quixote, La Época Ilustrada y El Rasca-Tripas. ${ }^{3}$ Aunque a primera vista pareciera que en todos los años que abarca la etapa en estudio hubo siempre periódicos con caricaturas, sucede que hay importantes lagunas, esto es, periodos de varios meses en los que nada se publicó. Ello se explica porque algunos de esos impresos sólo duraron unos cuantos números, por lo que apenas alcanzaron unos pocos meses y muy difícilmente llegaron algunos a cubrir el año. También porque en el caso de los que tuvieron una mayor duración, sucede que a veces suspendían su publicación por algún tiempo, lo que provoca que, en ocasiones, cuando el asunto de la libertad de imprenta cobró relevancia -ya porque se dictara alguna medida regulatoria, porque tuviera lugar algún suceso importante o fuera tema de discusión nacional-, no se cubriera desde la sátira visual. Pese a ello, encontramos en este periodo varias imágenes que atienden a la materia; de algunas caricaturas publicadas en esos impresos nos ocuparemos en las siguientes páginas para reconstruir las formas con las que contribuyeron a conformar ciertos imaginarios sobre el tema.

Interesa a esta investigación indagar sobre las representaciones que se elaboraron desde las caricaturas respecto de la libertad de imprenta y de expresión en lo que se refiere a ciertas políticas nacionales relevantes, ${ }^{4}$ así como las relaciones y tensiones que

${ }^{3}$ Empezó a circular en el último año de nuestro estudio La Patria Ilustrada, que llegaría a 1896, publicándose de manera ininterrumpida.

${ }^{4}$ Las condiciones que privaron en los estados fueron variadas y los estudios de caso sobre el tema están aún en ciernes. 
el ejercicio de ellas provocó entre los integrantes de la prensa y las autoridades gubernamentales. Centraremos nuestra atención, por un lado, en los periódicos producidos en la ciudad de México en el periodo que abarca de 1868 a 1883, esto es, del restablecimiento de la ley de 2 de febrero de 1861, conocida como Ley Zarco, ocurrido tras la reinstalación de la República, a la reforma constitucional del artículo séptimo, que garantizaba la libertad de expresión, y, por el otro, en la reconstrucción del marco regulatorio vigente durante ese periodo.

Cabe señalar que no haremos aquí un estudio exhaustivo de la producción de caricaturas sobre la materia, porque lo que nos interesa es el tratamiento que en algunas de ellas se hizo de las medidas más importantes, esto es, cuando se autorizaron facultades extraordinarias o suspensión de garantías que afectaban directamente a la libertad de imprenta, cuando se dictaron leyes en el mismo sentido o cuando se desplegaron acciones extralegales. ${ }^{5}$ Ubicamos un total de 12 caricaturas relativas a la materia que, podemos afirmar, son las más representativas en relación con la emisión de leyes y regulaciones, así como acciones violentas que afectaron a los impresos. De siete de ellas damos cuenta en el cuerpo central de este artículo, de las otras cinco nos ocupamos en notas, que complementan o ilustran alguno de los temas. Sólo para dar una idea, baste decir que El Abuizote, uno de los más longevos y, sobre todo, uno de los más críticos periódicos del régimen lerdista, en sus tres años de vida (1874-1876), que sumaron un total de 91 números, con entre tres y cuatro caricaturas por número (esto es, publicó entre 273 y 364 imágenes), dedicó 12 a la libertad de imprenta pero de ellas sólo en dos el tema fue central. ${ }^{6}$ En un caso extremo, El Tecolote (1876), en

${ }^{5}$ Las facultades extraordinarias y la suspensión de garantías se decretaban para diversas materias, por lo que no siempre afectaban a la libertad de imprenta. ${ }^{6}$ Una de ellas, la correspondiente al 23 de abril de 1875, no se incluye aquí porque está en relación con un proceso judicial específico y no con las medidas generales que afectaban a la prensa. 
sus 23 números, con una caricatura por número, no dedicó ni una sola de sus imágenes al tema de la libertad de imprenta, pero ello quizá se explica por el hecho de que su razón de ser era la contienda electoral.

Desde la caricatura de época y desde la historiografía, la relación entre el gobierno y la prensa ha sido vista, para el siglo XIX mexicano, especialmente para la segunda mitad, como una especie de guerra entre buenos y malos, asociando a los malos con el gobierno y a los buenos con la prensa, pero no con toda la prensa sino con aquella adjetivada como “independiente”. Así los gobiernos denominados -en su momento por esos impresoscomo tiránicos, dictatoriales o despóticos persiguen a la prensa, le ponen candados, la atan, la maniatan, la someten y buscan, en realidad como fin último, aniquilarla. Pero, en general, poca atención se presta a las complejidades de esa relación, que parece ser un binomio pero que en realidad tiene varias caras y diversos actores; que no es, aunque así se le quiera hacer parecer, unidireccional ni tiene protagonistas tan fácilmente identificables. Poca atención se presta, también, al tema de las conflictivas relaciones que ciertas medidas o acciones relacionadas con la libertad de imprenta provocaron entre las autoridades gubernamentales y los miembros del mundo de los impresos.

En tal contexto de preocupaciones, el objetivo de nuestro estudio es indagar en torno a la forma en que las representaciones sobre las disposiciones gubernamentales o ciertas situaciones -en ocasiones violentas-, plasmadas en las caricaturas políticas sirvieron para elaborar un discurso sobre la manera en que afectaban al periodismo esas medidas y acciones -legales o noinstrumentadas por las autoridades en relación con la libertad de expresión y de imprenta, en la búsqueda de la regulación -¿ ¡ podemos decir: el control?-por parte del gobierno sobre la prensa.

Por último, cabe señalar que la historiografía sobre la legislación de la libertad de imprenta para el periodo del que aquí nos ocupamos es realmente escasa. El tema ha sido apenas abordado, 
casi siempre de manera sucinta, y generalmente de forma poco precisa. ${ }^{7}$ Con el afán de subsanar la deficiencia que existe en el conocimiento en la materia nos dimos a la tarea de revisar con detenimiento la normatividad para aclarar cuál era la regulación vigente en cada momento, de lo que también dan cuenta los dos anexos incluidos en este trabajo.

\section{LA TORTUOSA LEGISLACIÓN VIGENTE:}

EL MARCO REGULATORIO DE LA LIBERTAD DE IMPRENTA

Un pequeño, delgado y frágil hombre, que va descalzo y cuyos ropajes no son otra cosa que planas de papel periódico, caracteriza a la libertad de imprenta. A su débil aspecto se suma la circunstancia de encontrarse preso, inmovilizado con apretados grilletes y varias cadenas, todas de gran tamaño. Un terrible y colosal criminal debía de ser para requerir tres grilletes en la pierna izquierda, dos en la derecha y uno en cada muñeca, además de sujetar una cadena su cuello hasta casi asfixiarlo. Por si todas esas medidas de seguridad fueran pocas, para acallarlo un inmenso candado atraviesa su mandíbula, descolgándola. Tiene el rostro desfigurado, por el peso mismo del candado, pero también acusando el maltrato recibido. Así se representaba a la "Libertad de imprenta" en una imagen publicada en las páginas de $\mathrm{La}$ Orquesta el 19 de enero de 1870 (caricatura 1). El mensaje de la caricatura es evidente: los miembros de la prensa, al menos de una parte de ella, se sentían profundamente amenazados y totalmente indefensos ante las disposiciones legales; o al menos así pretendían mostrarse frente a las medidas gubernamentales.

La caricatura aludía a la aprobación del 17 de enero, mediante la cual el Congreso de la Unión concedía al Ejecutivo

7 Algunos de los trabajos que se ocupan del tema son los del Chávez Lomelí, Lo público; y Gómez de LARA et al, Estudios. Nosotros lo hemos hecho en Gantús, Caricatura. También remitimos a la introducción de este dossier. 


\section{Caricatura 1}

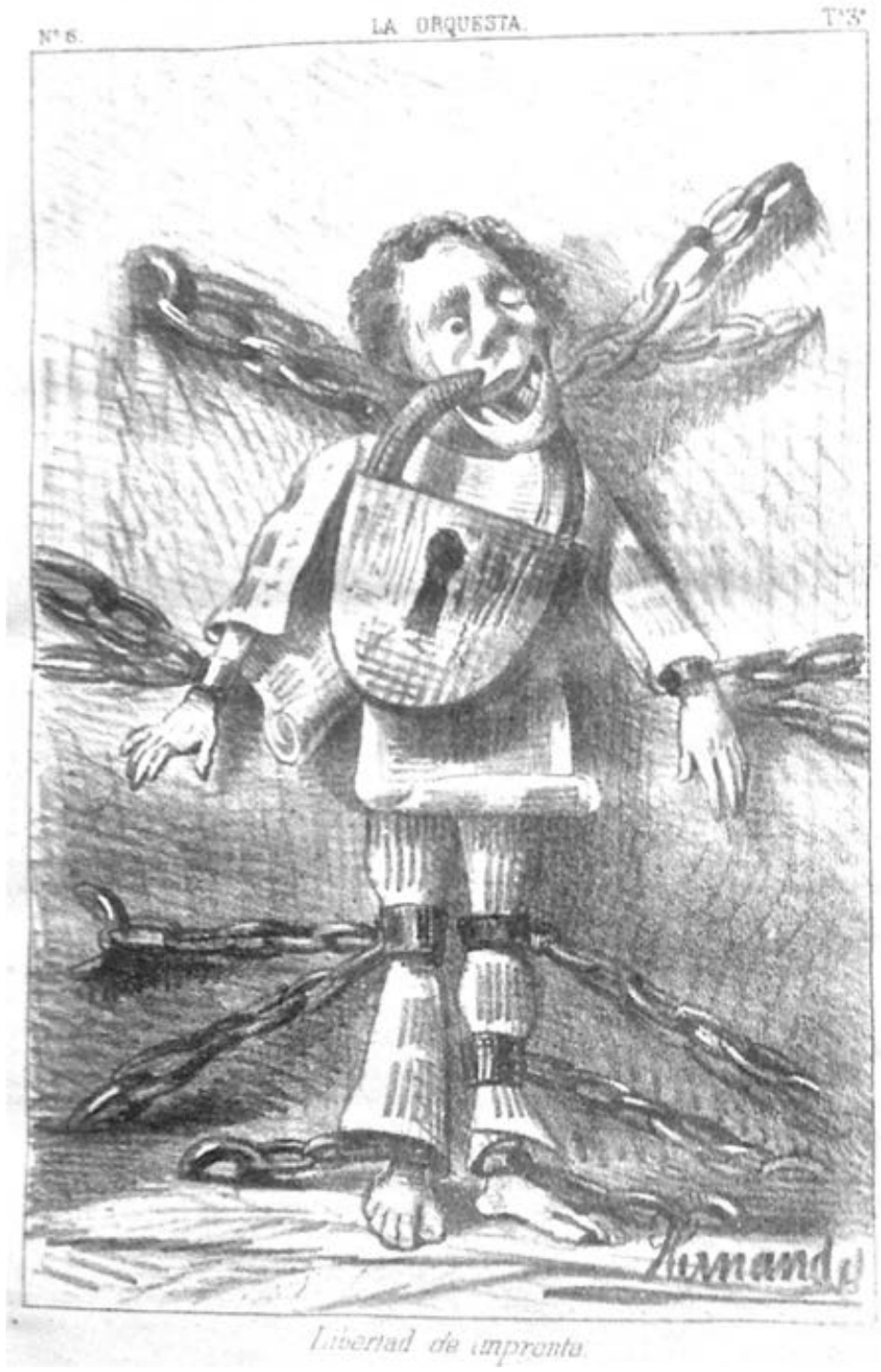

“Libertad de imprenta”, La Orquesta (19 ene. 1870). 
federal facultades extraordinarias, autorizaba la suspensión de garantías y restablecía la ley de 28 de diciembre de 1855 (segunda Ley Lafragua). ${ }^{8}$ Con esa acción se suspendía la vigencia de la Ley Orgánica de la Libertad de Prensa, reglamentaria de los artículos $6^{\circ}$ y $7^{\circ}$ de la Constitución Federal, que había sido decretada el 4 de febrero de 1868 (véase anexo 1). ${ }^{9}$ La ley que se restableció, en efecto, como acusaba la imagen satírica, era totalmente restrictiva y dejaba muy poco margen de acción para el ejercicio periodístico. Depositaba la responsabilidad de lo publicado sobre autores e impresores y entre los abusos de la libertad de imprenta que tipificaba se contaban: el ataque a la religión católica o a la forma de gobierno; la publicación de noticias falsas o alarmantes, así como de escritos obscenos; el excitar a la rebelión o al desorden; y escribir contra la vida privada. ${ }^{10}$ Pero éstas eran sólo algunas de las muchas prohibiciones que la ley contenía.

El tema de la legislación, si bien siempre referido como el obligado marco que hace inteligibles las dinámicas prensa-gobierno, ha sido en realidad poco discutido con seriedad desde la historiografía debido a su complejidad. En efecto, a las leyes sobre la materia hay que sumar acuerdos y resoluciones del Congreso de la Unión y del Ejecutivo nacional, comunicados por medio de decretos, bandos y circulares, que regulan su vigencia (promulgación, suspensión o derogación), así como el otorgamiento de facultades extraordinarias y suspensión de garantías, que también las modifican o condicionan, y aun de manifiestos oficiales y proclamas revolucionarias que las afectan. El marco

\footnotetext{
${ }^{8}$ Sobre el tema de las facultades extraordinarias véanse, entre otros, Aguilar, Manto liberal, pp. 231-268; Arenal, "Juárez", pp. 163-176; Martínez BÁEZ y Tena Ramírez, Suspensión de garantías, 65 p.

${ }_{9}$ Constitución Federal, 1857.

${ }^{10}$ Ley de 28 de diciembre de 1855, Dublán y Lozano, Legislación, t. VII, 1877, pp. 633-636.
} 
legislativo en vigor en cada momento o coyuntura relevante es pues muy complejo y poco conocido. ${ }^{11}$

Tras el triunfo de la República sobre el Imperio, con Benito Juárez de nuevo en la presidencia, el 11 de enero de 1868 se emitió una circular informando del restablecimiento de la ley de 2 de febrero de 1861 (Ley Zarco), "que había sido calificada como la más liberal que se había conocido en la materia". ${ }^{12}$ Esa ley en realidad estuvo vigente apenas unos pocos meses, ${ }^{13}$ pues en ese mismo año, el 7 de junio, basado en el argumento de las difíciles condiciones que atravesaba el país, la Cámara de Diputados concedió al mismo Juárez garantías especiales y el presidente decretó el restablecimiento de la ley de 28 de diciembre de 1855 (segunda Ley Lafragua), la cual rigió durante todos esos años: del 7 de junio de 1861 al 11 de enero de 1868 (véase anexo 1). ${ }^{14}$

Poco menos de un mes más tarde, esto es, el 4 de febrero de 1868, el gobierno mediante decreto informaba de la promulgación autorizada por el Congreso de la "Ley Orgánica de la libertad de la prensa, reglamentaria de los artículos $6^{\circ}$ y $7^{\circ}$ de la Constitución Federal”. Esta nueva legislación era, en realidad, la misma del 2 de febrero de 1861 (Ley Zarco), pero ahora elevada al rango de ley orgánica. Por primera vez en muchos años, el escenario para la prensa parecía prometedor; pero el estado de amplia libertad para la imprenta duró menos de un año, pues

${ }_{11}$ Para lo concerniente a la primera mitad del siglo y el Segundo Imperio, véase Coudart, “Regulación”, pp. 629-687.

${ }_{12}$ Francisco Zarco, "La Ley de imprenta”, El Siglo Diez y Nueve (27 jun. 1868). Tan sólo unos meses después de emitida, en un comunicado respecto a esa ley apuntaría el propio Zarco que "garantiza[ba] a la prensa una libertad y una independencia como nunca se había disfrutado en la República". Circular del 21 de marzo de 1861. Dublán y Lozano, Legislación, t. IX, 1878, pp. 126-127.

${ }^{13}$ Como señala Coudart, en su primera etapa sólo alcanzó cuatro meses de vigencia. COUDART, “Regulación”, pp. 629-630.

${ }^{14}$ Aunque entre 1864 y 1867 se empalma con la legislación imperial, de la cual no nos ocupamos por quedar fuera del periodo que comprende este estudio. 
de nuevo Juárez recurrió a las facultades extraordinarias y el 17 de enero de 1870 se restableció la ley de 28 de diciembre de 1855 , la cual estuvo vigente hasta el 1o de abril de 1870 (véase anexo 1).

Esta nueva coyuntura, esto es, el término de ese periodo de facultades extraordinarias y con ello el restablecimiento de la Ley Orgánica de la Libertad de Prensa, dio pie a una imagen sobre el tema. En una caricatura, pretendiéndolo una ballena, según apunta el texto que la acompaña: "La ballena que se tragó a Jonás", se dibuja a un ser quimérico y monstruoso: con un cuerpo abultado y peludo, al igual que la cola, unas garras gordas y prominentes, una cabeza con largas mandíbulas con feroces colmillos y filosos dientes, que emerge del agua, especie de pantano más que de mar. Aferrándose con sus garras a la orilla abre sus fauces y de ellas emerge, huyendo presurosa, una indefensa mujer que había sido engullida por ese animal, como lo denota la pierna izquierda que aún está dentro de su garganta. Esa mujer, que va descalza, huye de ese monstruo y de su encarcelamiento, según lo sugieren los grilletes que con cadenas rotas trae en ambos brazos y en la pierna visible. En la mano izquierda sostiene las plumas del oficio que caracteriza: el del escritor y periodista. Para que no quede duda de a quién representa, en su túnica lleva la palabra "Imprenta", y remata la imagen la corona de laurel que porta. El monstruo lleva el rostro de Lerdo de Tejada, secretario de Relaciones Exteriores entonces, acusando así que era él quien había estado detrás de la medida y no el presidente Juárez (caricatura 2).

Ya hemos apuntado que con esta caricatura se celebraba el fin de la suspensión de garantías y el restablecimiento de la ley orgánica de la prensa. En efecto, el 1ㅇ de abril de 1870, al abrirse las sesiones del Congreso, el presidente se presentó ante los diputados y en su discurso, al "devolver" las facultades que le habían sido otorgadas, además de señalar que había "hecho el menor uso posible de ellas", respecto a la prensa apuntó: "Ha 


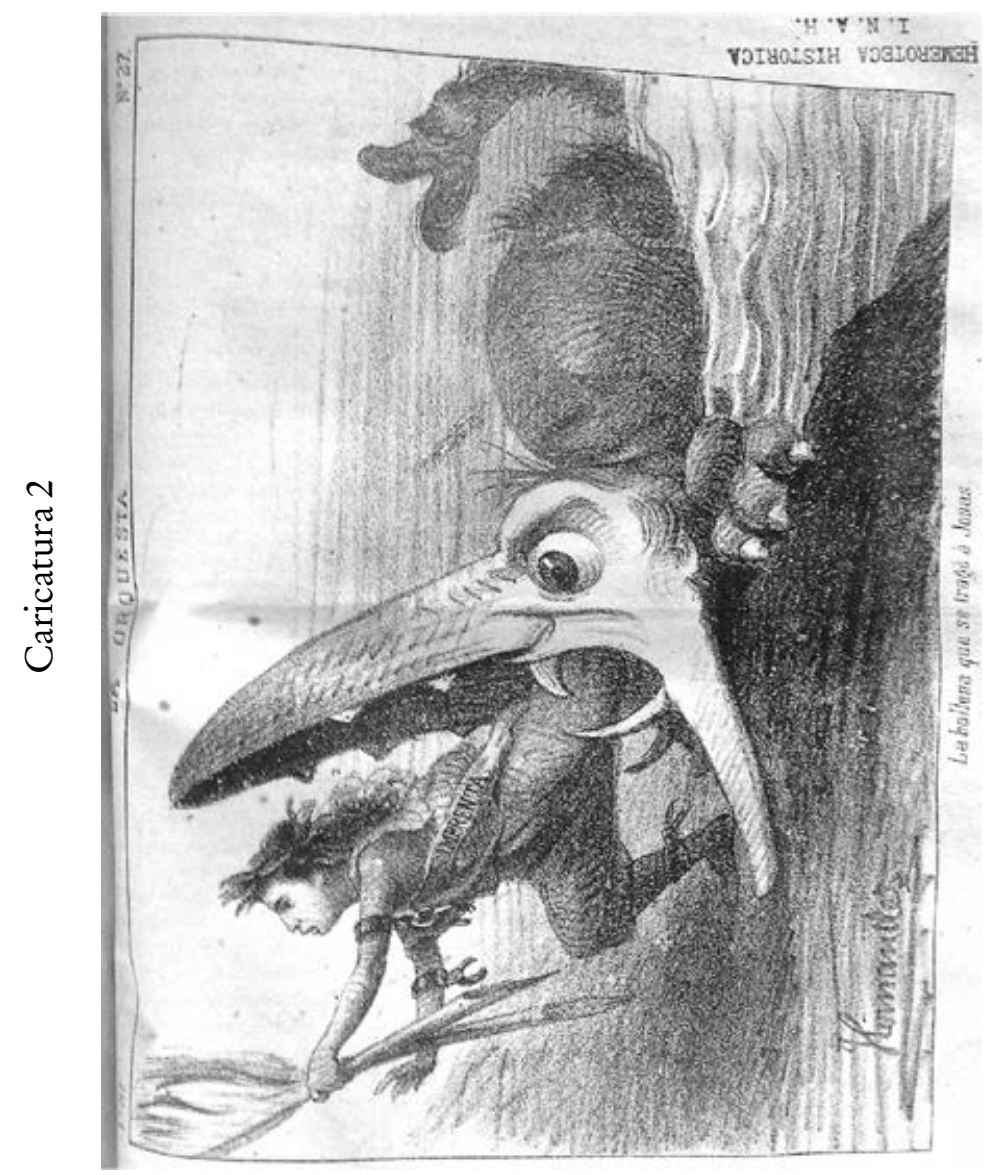

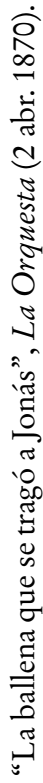


cuidado [el Ejecutivo] al mismo tiempo de que se respeten las garantías individuales, y ha mantenido de hecho la plena libertad de la prensa, no determinando en algunos abusos de ella los procedimientos autorizados por la ley". ${ }^{15}$

Como se desprende de la confrontación de las dos imágenes mostradas con las palabras pronunciadas por el primer magistrado del país, las realidades que se pintan son muy diferentes. Mientras las caricaturas exponen una crítica situación de presión y límites severos contra la prensa, el presidente aseguraba que la libertad de prensa fue, a pesar del otorgamiento de la suspensión de garantías, ampliamente respetada. Lo cierto es que, con razones o sin ellas, el régimen juarista viviría sus últimos años prácticamente parapetado en el uso de facultades extraordinarias y la suspensión de garantías, otorgadas una y otra vez por el Congreso, en diferentes materias. ${ }^{16}$ En efecto, en el caso de la libertad de imprenta la situación de excepción se tradujo en una regulación acotada, de enero a marzo de 1870 por la restrictiva ley de 28 de diciembre de 1855. Desde abril volvió a regir la Ley Orgánica de la Libertad de Prensa y con ello las libertades que otorgaba. Aunque el 2 de diciembre de 1871, como consecuencia del estado de excitación política visible en varios movimientos armados declarados en distintas regiones del país, pero especialmente como

15 "Sesión del 1o de abril de 1870 de la Cámara de Diputados", El Siglo Diez y Nueve (2 abr. 1870).

${ }_{16}$ El uso de las facultades extraordinarias por parte de Juárez llevó a que en las páginas de La Orquesta lo pintaran como un pequeño hombrecito que ambicionaba poderes imperiales, pero que no tenía el tamaño para llevar la corona y el cetro, que sobrepasan sus dimensiones. Lo que sí hacía era valerse de ese recurso legal para, en opinión del caricaturista, sembrar la desolación y la muerte en todo el territorio nacional, someter al empobrecido pueblo a mayores contribuciones, imponerse a la justica, aniquilar a la religión y aprisionar a la imprenta. Así, la caricatura muestra a la "Justicia” como una débil mujer que, aprisionada por un poderoso grillete que la inmoviliza, apenas puede sostener su espada, en tanto sobre la libertad de imprenta pesa un poderoso candado que la tiene sometida y le impide usar sus herramientas. La Orquesta (29 nov. 1871): "Lo que producirán las facultades extraordinarias". 
consecuencia del estallido de la revuelta de La Noria, cuyo Plan se pronunció el 9 de noviembre, de nuevo se autorizó la suspensión de las garantías, la misma no afectó lo relativo a la materia de libertad de expresión, lo que supone que continuó vigente la Ley Orgánica de la libertad de prensa de 1868.

Con la muerte de Juárez, ocurrida el 18 de julio de 1872, Sebastián Lerdo de Tejada asumió la presidencia, primero de manera provisional y luego, tras celebrarse las elecciones, de forma constitucional. En el manifiesto que como presidente de la República emitió Lerdo de Tejada el 27 de julio de 1872 concediendo amnistía política a los sublevados, respecto a la libertad de prensa, señalaba: "la libertad de la prensa, que protege y resguarda a las otras, será para mí inviolable [...] Si la libertad de escribir no debe en cualquier época tener limitación alguna, menos debe tenerla en un periodo de lucha electoral". ${ }^{17}$ En ese mismo manifiesto fue donde hizo suya una frase que estaba en el ambiente desde tiempo atrás respecto a la prensa, que adquiría así un peso especial al ser reconocida por la autoridad presidencial como una estrategia básica que respecto al periodismo debía seguir el gobierno: "De los excesos que se cometan por la prensa, el mejor correctivo es la misma prensa, ilustrada, libre, eco de todas las opiniones, y de todos los partidos". ${ }^{18}$

La siguiente disposición legislativa relativa a la imprenta, ya bajo la presidencia de Lerdo de Tejada fue la reforma del artículo 42 de la ley orgánica de la libertad de prensa, ocurrida el 1o de mayo de $1875 .{ }^{19}$ Así, podemos señalar que entre julio

17 Manifiesto de Sebastián Lerdo de Tejada a sus conciudadanos, 27 de julio de 1872. Recopilación de leyes, t. XVI, 1873, pp. 283-2287.

18 Recopilación de leyes, t. XVI, 1873, pp. 283-2287. Francisco Zarco había sido uno de los intelectuales mexicanos que más convencidos había estado de esa idea, la que sostuvo en los debates del Constituyente de 1856-1857 y en sus notas periodísticas.

19 La reforma apuntaba que todo impreso debía contener fecha, oficina tipográfica, nombre del propietario y firma del autor. Dublán y Lozano, Legislación mexicana, t. XII, 1882, pp. 716-717. 
de 1872 y octubre de 1876 rigió en la República esa ley, la cual daba amplias libertades a la prensa. Sin embargo, de nuevo por la situación de agitación que se vivía en el país, asediado por la sombra de la revuelta, Lerdo recurrió también a las facultades extraordinarias. Con sublevaciones armadas en diversos estados y el pronunciamiento de Tuxtepec que estalló a principios del año de 1876, el Congreso de la Unión expidió el 14 de octubre la ley de facultades extraordinarias que, una vez más, autorizó la suspensión de la libertad de imprenta, la que privaría hasta el fin de su presidencia.

El uso de las facultades extraordinarias por parte del presidente Lerdo dio pretexto a su principal opositor en la prensa satírica, El Abuizote, para crear un par de caricaturas sobre el tema. ${ }^{20}$ La primera apareció en marzo de 1876; en ella se muestra a los principales representantes de la prensa que, con candados en los labios, escuchan atentamente a Darío Balandrano, redactor en jefe del Diario Oficial, leer una nota aparecida en ese periódico. Ahí están caracterizados, de izquierda a derecha, Vicente García Torres, director de El Monitor Republicano; con la representación de los personajes que daban título a los impresos le siguen El Hijo del Abuizote y El Padre Cobos; el último de la fila es Enrique Chavarri, conocido como Juvenal, escritor de El Monitor Republicano (caricatura 3) ${ }^{21}$ Resulta notorio que en esta caricatura, a pesar de los candados que los silencian, no parece haber en realidad temor por parte de los miembros del gremio; tienen una actitud pasiva pero están tranquilos. Parece más bien una franca burla al colega encargado del periódico oficial y su diatriba.

El Diario Oficial se había dirigido en diversas ocasiones a la "prensa oposicionista" expresando la intención del gobierno de

20 El Abuizote (10 mar., 16 jun. y 13 dic. 1876).

${ }^{21}$ El personaje que aparece en segunda fila no lo hemos podido identificar suficientemente, pero consideramos que puede tratarse de Gonzalo Esteva. 
Caricatura 3

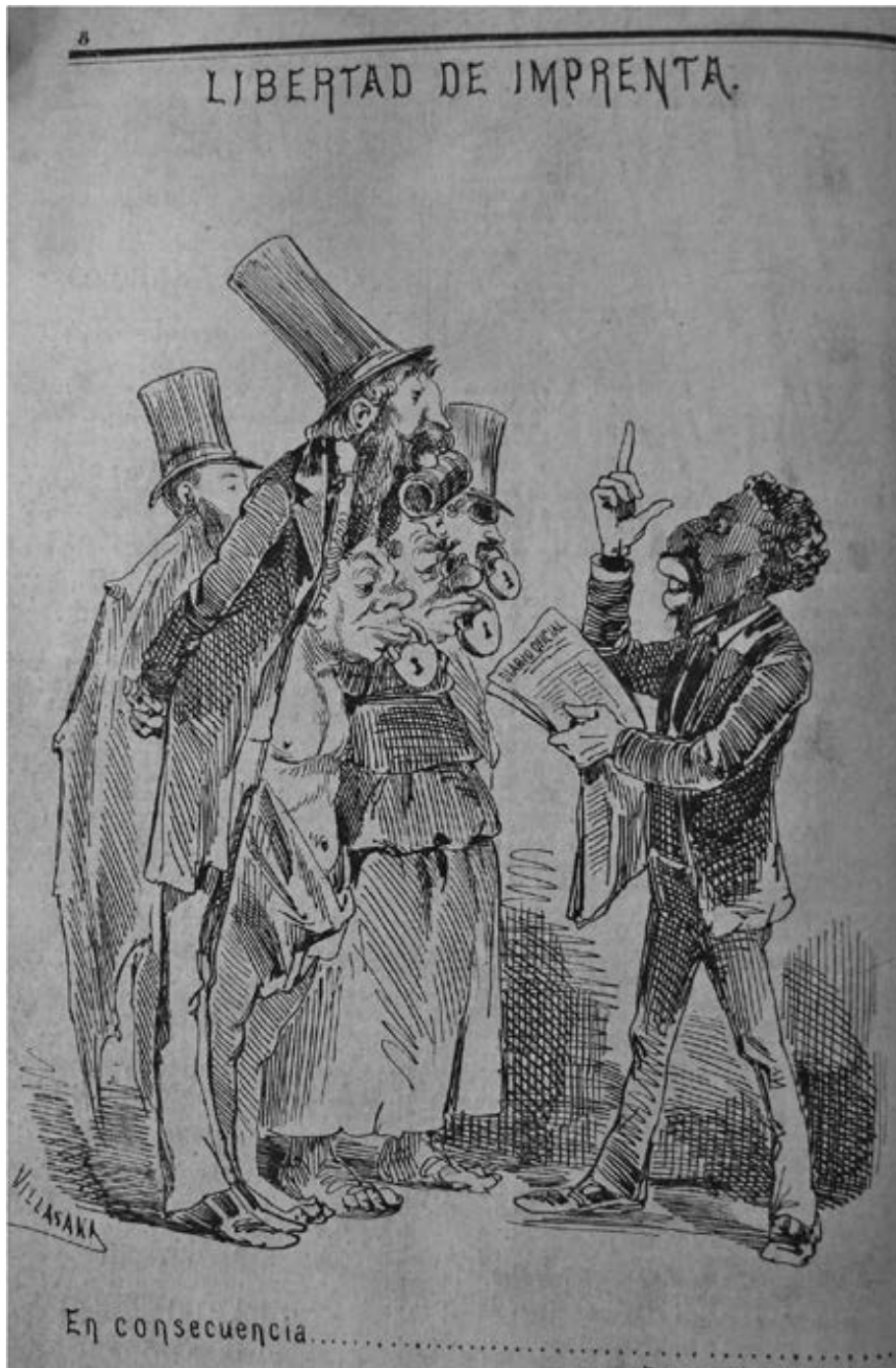

(DIARIO OFICIAL)

“Libertad de imprenta”, El Abuizote (10 mar. 1876). 
respetar la libertad de imprenta pero advirtiendo que la misma no se podía extender a las "publicaciones que proclaman abiertamente la rebelión, o la fomentan publicando proclamas y esparciendo noticias notoria y evidentemente falsas". ${ }^{22}$ Ante tal situación, apuntaba el impreso oficial a principios de marzo, el gobierno se veía obligado a "reprimir conducta tan perjudicial” con la finalidad expresa de “conservar la paz pública” y también por la necesidad de "poner un límite entre la verdadera libertad de imprenta, y los abusos”. Concluía advirtiendo a los periódicos que tenían ese carácter que de continuar con esa línea editorial "el ejecutivo se ver[ía] en la forzosa necesidad de proceder contra esas publicaciones". ${ }^{23}$

Poco antes de abandonar la presidencia, lo que ocurriría en noviembre, fundado en la gravedad provocada por la revolución que se extendía por el territorio nacional, el 14 de octubre, como ya hemos anotado, el Congreso concedió a Lerdo de Tejada una nueva prórroga de las facultades extraordinarias, suspendiendo también las garantías concedidas para la libertad de expresión. Una de las razones aducidas para otorgar tal suspensión fue que "la prensa oposicionista se desbordó de una manera escandalosa, abusando de la libertad que concede el art. $7^{\circ}$ de la Constitución y de la ilimitada tolerancia del ejecutivo de la Unión”. ${ }^{24}$

\footnotetext{
22 Diario Oficial (7 mar. 1876).

23 Diario Oficial (7 mar. 1876). Unos meses más tarde se publicaría una caricatura en varias páginas y múltiples recuadros en los que criticaban diversas acciones del gobierno. Como en el caso de Juárez, se dibujarían a las facultades extraordinarias como el signo de las aspiraciones imperialistas del presidente Lerdo, representadas en una corona y un cetro, y a la libertad de imprenta sometida por grilletes y candados. Esta última muestra su complejidad, pues el gobierno, sintiéndose amenazado por el periodismo que apoyaba la revuelta, consideraba imprescindible contenerla, y el periodismo de oposición, por su parte, criticaba las acciones del gobierno para defender su causa que atentaba contra el orden constitucional. El Abuizote (16 jun. 1876): "Una mirada retrospectiva y otra perspectiva [cuarta parte]". Detalle.

24 Dublán y Lozano, Legislación mexicana, t. XIII, 1886, pp. 85-87.
} 
Como lo fuera en su momento Juárez, Lerdo de Tejada también sería fuertemente criticado desde la sátira visual por el uso de las facultades extraordinarias. Aun cuando ya había abandonado la presidencia, la sombra de esos poderes excepcionales ejercidos durante su mandato continuarían siendo el arma para demeritar su reputación..$^{25}$ Así, aunque el gobierno de Lerdo de Tejada fue mucho más liberal, en la medida en que por casi cuatro años se observó la Ley Orgánica de la Libertad de Prensa, terminó, sin embargo, usando las facultades extraordinarias y suspendiendo diversas garantías, entre ellas la de la libertad de imprenta.

Triunfante la revolución de Tuxtepec, y habiendo accedido al gobierno, se hacía efectivo lo consignado en el plan del mismo nombre, del 10 de enero de 1876, uno de cuyos artículos señalaba el carácter supremo de la Constitución de 1857, lo que supone que la suspensión de garantías otorgada a Lerdo perdía vigor. Sin embargo, hay poca claridad al respecto. Aunque hemos revisado las disposiciones oficiales emitidas entre 1876 y 1883, lo único que hemos encontrado respecto a la libertad de imprenta es la formación en 1882, en la Cámara de Diputados, de una comisión encargada de elaborar una ley orgánica para regular el artículo $7^{\circ}$ constitucional (véase anexo 1). Lo que sí sabemos es que Porfirio Díaz intentó, en 1880, recurrir a las facultades extraordinarias, para lo cual en marzo solicitó autorización al Congreso con el fin de suspender las garantías individuales para ladrones, plagiarios y salteadores de caminos pero sin obtener resultados favorables, por lo que tuvo que renunciar a su pretensión. ${ }^{26}$

25 En una caricatura de El Abuizote se le dibujó como una especie de emperador romano que mediante el uso de facultades extraordinarias había sometido al país de diversas formas y convertido a la "libertad de imprenta" en un perro servil. En realidad, la caricatura respondía a los intereses de los redactores del semanario satírico que, aliado de la causa tuxtepecana, necesitaba reforzar su posición frente al gobierno derrocado. El Abuizote (13 dic. 1876): “Exe Homo".

26 “Comisión permanente, sesión de 23 de marzo de 1880”, El Siglo Diez y Nueve (25 mar. 1880). 


\section{EL PROBLEMÁTICO SÉPTIMO CONSTITUCIONAL}

La reforma del artículo séptimo constitucional es otro de los temas obligados al tratar la libertad de imprenta (véase anexo 2). ${ }^{27}$ Sobre el mismo hay claridad en cuanto a su promulgación, decretada el 15 de mayo de 1883, bajo la presidencia de Manuel González. Aunque menos claridad ha habido respecto a los intentos previos y a las discusiones mismas que la propuesta provocó en ambas cámaras, de diputados y de senadores, durante $1882 .{ }^{28}$ En este contexto, cabe preguntarse cuál es el discurso que sobre el tema se construyó desde la sátira visual. ${ }^{29}$

Con sendas hachas que -por su tamaño y peso- requieren ser sostenidas con ambas manos, aparecen al centro de la escena dos hombres cuyo aspecto choca con la acción que realizan. Se trata de individuos de edad madura, apariencia pulcra, vestidos de traje, ambos barbados, con espejuelos y con gesto serio, que denota la gran concentración con la que desempeñan su tarea. Contrariamente a lo que su aspecto sugiere, su tarea es la de un guerrero o un leñador, esto es, atacar a un enemigo en la batalla o echar abajo un árbol. La escena, por paradójica, resulta desconcertante para quien la observe. Se trata de dos personajes muy conocidos en el espacio público y en la vida política de la época: Guillermo Prieto y Pedro Santacilia, los dos diputados federales

\footnotetext{
27 Sobre el tema del artículo séptimo constitucional véase, entre otros, FerreIRO, "Libertad"; Gómez de Lara et al, Estudios, pp. 25-28.

${ }^{28}$ Sobre esta reforma y sus antecedentes, esto es, los intentos realizados en 1868 y 1871, véase GanTús, Caricatura, pp. 219-304.

29 Y también hay que interrogarse sobre la "veracidad" de ese discurso. ¿De qué elementos se vale, qué es lo que denuncia, a qué situaciones corresponde y, sobre todo, qué es lo que persiguen (realmente les interesa la defensa de la libertad de expresión o de "su" libertad pero no la de todo el gremio), qué intereses defienden (y cuáles se esconden detrás)? Valdría la pena preguntarse si esa denuncia tiene correlato en los hechos del momento.
} 
en ese momento. ${ }^{30}$ Las hachas que sostienen representan a la "Nueva ley" o "Nuevo proyecto de Ley de Imprenta”, cuya iniciativa ambos suscribieron y presentaron de forma conjunta ante la Cámara de Diputados del Congreso de la Unión. Esas hachas son las armas que con contundencia dejan caer sobre un hombre de edad avanzada quien, indefenso, se encuentra tirado en el piso en la parte inferior del recuadro, después de haber sido derribado por la misma acción violenta, como lo dejan suponer las “cajas” que debió haber llevado en las manos y que yacen desperdigadas por el suelo. El individuo atacado es Vicente García Torres, director de El Monitor Republicano -periódico con más de un cuarto de siglo de vida-, quien como veterano de la prensa la simboliza (caricatura 4). ${ }^{31}$

En el centro de la escena, entre Prieto y Santacilia, sobre un pedestal se yergue la estatua de José María Lafragua quien, al estilo de Moisés con los mandamientos, lleva en las manos las "tablas" en que quedó consignada la ley sobre libertad de imprenta a la que dio nombre -en este caso la segunda, emitida el 28 de

30 Pedro Santacilia era un escritor liberal cubano, exiliado de la isla por sus ideas independentistas, incorporado a la vida política mexicana a partir de su vinculación con Benito Juárez, de quien era yerno. Guillermo Prieto, liberal reconocido, además de su amplia trayectoria como periodista, se había desempeñado en el Poder Legislativo desde 1862 y era un personaje asociado de cerca con el gobierno juarista, pese a las aristas de esa relación. Estos periodistas han "traicionado" al gremio en el afán de procurar los intereses del poder Ejecutivo, el cual parece evidenciarse detrás de sus acciones como legisladores. Aunque esto no está claramente expresado en la imagen, la idea de la sombra del Ejecutivo se reafirma -además de por los vínculos entre los diputados y Juárez- con la presencia de la Ley Lafragua, que denuncia la intención de perpetuar el uso de esa ley para limitar a la prensa, y alude también a Juárez mismo, pues durante su presidencia, en 1861, escudado en la situación alterada que vivía el país, suspendió la Ley Zarco y restableció la de Lafragua, la cual estuvo vigente hasta principios de 1868 . Y lo había estado en diversas ocasiones, hasta el momento mismo de publicarse la caricatura.

31 En enero de ese mismo año ese periódico había sido objeto de denuncias judiciales. El Monitor Republicano (25, 26 y 27 ene. 1872). 


\section{Caricatura 4}

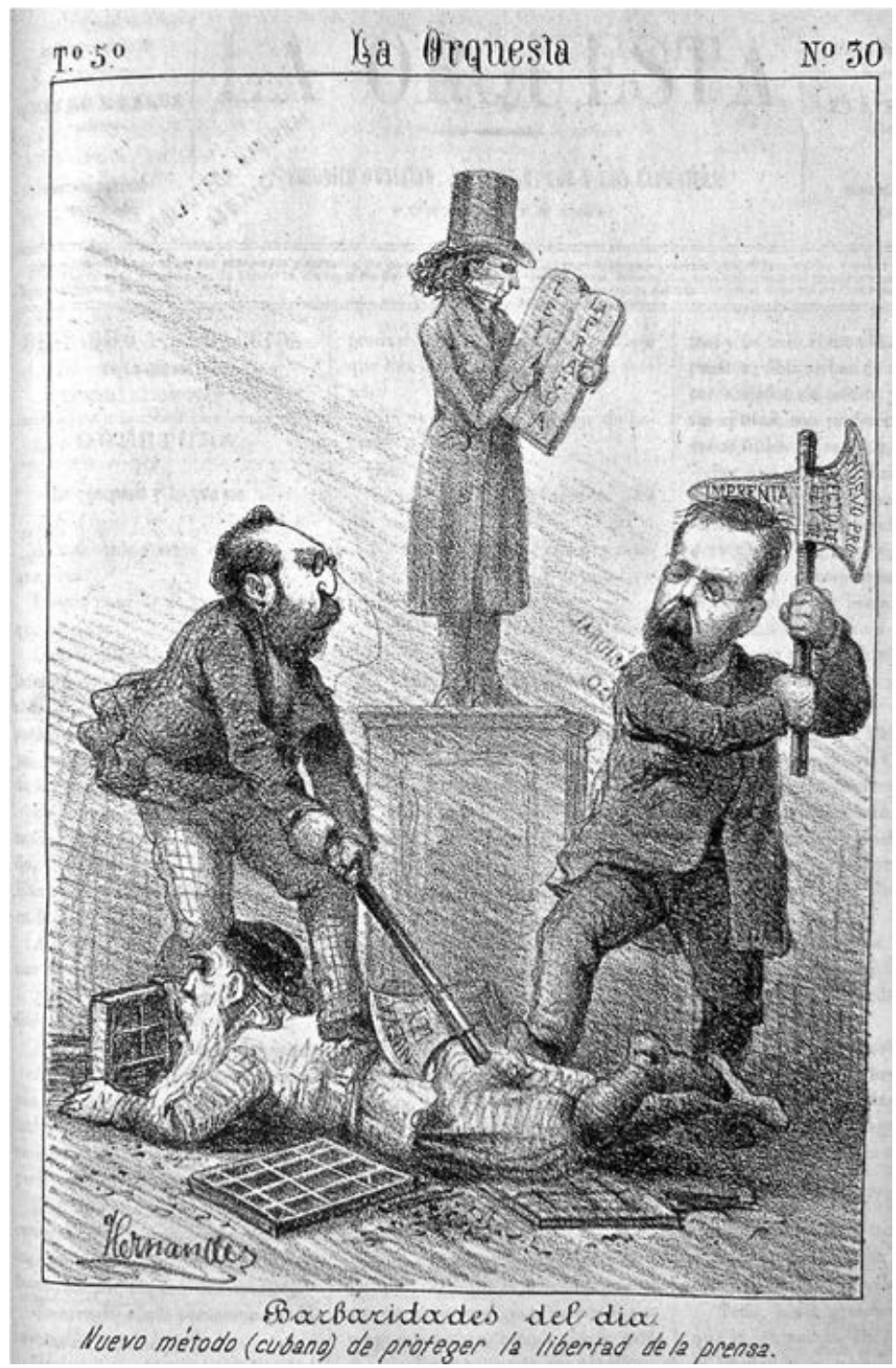

"Barbaridades del día”, La Orquesta (13 abr. 1872). 
diciembre de 1855-, y que ha sido considerada como una de las más severas y restrictivas. Lafragua es así el modelo que, según el semanario, los diputados buscan emular y la ley que concibiera el principio que se proponen rija al mundo de la imprenta. La "prensa" ha sido "traicionada", sugiere el hecho de que esté derribado boca abajo quien la representa y las hachas se claven en su espalda, pues quienes impulsan la reforma son también parte del gremio.

La caricatura enuncia la conflictiva situación mostrando la propuesta como una "amenaza" y patentiza los temores que genera; pero, sobre todo, sintetiza las complejidades del escenario político en relación con el tema que nos ocupa. Aunque no hay sangre, ni desmembramientos evidentes en la escena, toda ella sugiere una gran violencia: la ley que proponían destruiría brutalmente a la prensa. La imagen se complementa con el título y el subtítulo que la acompaña y que reafirma el toque irónico: "Barbaridades del día. Nuevo método (cubano) de proteger la libertad de la prensa”. Lo bárbaro es, al mismo tiempo, algo necio, pero también temerario, algo que es excesivo y causa asombro, pero también puede provocar extrañeza. El término cubano, por su parte, aludía al origen de Santacilia, nacido en la isla. Todo ello, sugiere la caricatura, se mezclaba en las acciones emprendidas por Prieto y Santacilia para regular a la prensa. La ley es presentada y representada en la imagen satírica como el arma brutal con la que las autoridades lograrán imponerse al mundo de la imprenta, socavarla y destruirla.

La caricatura apareció en abril de 1872, pero alude a la propuesta de reforma del artículo $7^{\circ}$ constitucional que ambos personajes, Prieto y Santacilia, en su carácter de diputados, habían presentado ante la VI Legislatura el 20 de septiembre del año anterior, 1871 (véase anexo 2). ${ }^{32}$ La propuesta consistía en

32 DDD (20 sep. 1871); El Correo del Comercio (12 abr. 1872); El Monitor Republicano (17 abr. 1872). 
modificar la parte final del artículo suspendiendo así los jurados populares para los delitos de imprenta. ${ }^{33}$ La pretensión de reformar el artículo que regulaba la libertad de imprenta no era nueva, pues se había intentado apenas tres años antes, en 1868. Lo que se perseguía con la reforma era, en realidad, eliminar el fuero a la prensa, esto es, que no hubiera tribunales especiales para juzgar los delitos de imprenta. ${ }^{34}$ En efecto, en la sesión del 5 de noviembre de ese año -1868- los diputados Pantaleón Tovar -también periodista-, Juan C. Doria y Narciso Dávila, todos representantes por Nuevo León, por lo que esa diputación lo hizo suyo, presentaron el proyecto de reforma constitucional (véase anexo 2). ${ }^{35}$ En esa ocasión -noviembre de 1868- no había en el escenario público ningún periódico con caricaturas; La Orquesta, que fue el semanario satírico con caricaturas que se desempeñó como crítico del gobierno juarista, había suspendido su publicación desde junio, por lo que el tema de la reforma del artículo séptimo constitucional no fue representado en la sátira visual del momento.

¿Por qué el muy liberal régimen juarista, de manera similar que los acusados de tiránicos o dictatoriales, como el santanista o el porfirista, también procuró el control de la prensa? ¿Debemos suponer por ello que en realidad el gobierno juarista no fue tan liberal? Esto es, ¿̨por qué un gobierno como el de Benito Juárez,

33 La comisión de la "libertad de imprenta", propuesta en la misma sesión -junto con todas las demás-, quedaría conformada por "Zamacona, Michel, Fernández R., y como suplente Esteva”. DDD (20 sep. 1871). La segunda lectura se dio en la sesión del 22 de septiembre, en la cual también fue admitido a discusión, aunque ello causó polémica, porque algunos diputados reclamaban que debía pasar primero a la comisión de puntos constitucionales, $D D D(20$ sep. 1871).

${ }^{34}$ Sobre el fuero de la prensa y la necesidad de suprimirlo, véase, por ejemplo, Vallarta, Cuestiones, pp. 354-355, y Cuestiones, pp. 331-332. El tema lo trabajamos en GANTús, Caricatura, pp. 280-312.

${ }^{35}$ La misma fue turnada a la comisión de puntos constitucionales. $D D D$ (5 nov. 1868). 
al que se ha considerado de “avanzada” por sus leyes progresistas, por la observancia de las garantías individuales y por el respeto a la libertad de imprenta, entre otras acciones, y personajes como Guillermo Prieto, intelectual destacado y liberal respetado como tal, buscaron, según se les imputó, restringir la libertad de imprenta y expresión?

Intentemos responder algunas de estas interrogantes. Del análisis de estas imágenes y de la situación descrita, en principio, lo más simple sería destacar que el régimen juarista procuró poner límites más severos a la prensa porque le disgustaba la existencia de jurados populares en los juicios relacionados con la imprenta ya que los consideraba parciales, pues en la mayoría de los casos fallaban a favor del acusado, esto es, de los miembros del periodismo. ${ }^{36}$ Así, la iniciativa de Prieto y Santacilia de 1871 podríamos entenderla simplemente como un nuevo intento del gobierno juarista por contener y controlar a la prensa -el anterior había ocurrido en 1868- (véase anexo 2). ${ }^{37}$ Podemos enmarcarla en la idea sostenida por Juan N. Mirafuentes de que

\footnotetext{
36 Sobre los jurados de imprenta y su supresión remitimos a Speckman, "Justicia".

37 En 1871, tras la presentación de la propuesta de reforma y antes de la caricatura analizada, La Orquesta, en su tercera época de publicación, dedicó una imagen al tema. Se trata de una sátira visual publicada el 31 de octubre, con motivo del Día de Muertos próximo, en la que se muestra una especie de altar dedicado a la Constitución, cuya ofrenda es una calavera. Las cavidades orbitarias de la misma son los rostros de Prieto y Santacilia quienes, cubiertos en manos, el primero lleva el cuchillo y el segundo un tenedor, se disponen a degustar el platillo que hay entre ellos y que reposa sobre la mesa del "erario", que es en realidad la dentadura de la calavera. Pero ambos miran con gesto entre sorprendido e incrédulo, porque lo que se disponen a comerse es una especie de lámpara cuya luz está protegida por una pantalla que representa al gorro frigio, con el que al mismo tiempo se dibuja la cavidad nasal. Tal es la ofrenda que "D. Benito" hace a la Constitución. Complementan el conjunto de la imagen dos tibias cruzadas, cada una rematada con un rostro, al parecer los de Ignacio Mariscal y Porfirio Díaz. La Orquesta (31 oct. 1871), "La ofrenda de D. Benito".
} 
“para el juarismo la nación es Juárez, la voluntad de éste la ley suprema y su capricho la regla invariable de la política”. ${ }^{38}$ Pero el asunto no es tan sencillo. El hecho de que Juárez y Prieto, figuras señeras del liberalismo mexicano, hayan buscado en dos ocasiones la reforma del artículo séptimo constitucional, el hecho de que el mismo Prieto haya manifestado, ya desde los debates del constituyente de 1857, su disconformidad con los artículos sexto y séptimo tal cual quedaron consignados, pone en evidencia lo complejo del tema de la libertad de imprenta. Este es exactamente el punto que quiero sostener: que las relaciones entre la prensa y el gobierno fueron, a lo largo de la centuria decimonónica, un tema muy complejo, lleno de aristas, con límites difusos, plagado de acusaciones y reproches, marcado por discursos y figuras contradictorias y debates múltiples. Entender pues, o más exactamente, intentar entender el tema de la libertad de imprenta y expresión, exige prestar atención a perspectivas y posicionamientos varios.

Ni en 1868 ni en 1871 prosperó el intento de modificar el artículo constitucional, por ello el recurso de que se valió el gobierno juarista fue el de la suspensión de garantías. De manera parecida procedería Lerdo de Tejada, conocedor de estos antecedentes -con una situación política muy difícil que afrontar desde el inicio de su gestión, que se fue agravando con el paso de los años y llegó a su momento crítico en 1876-; ni siquiera se planteó el tema. Cuando tuvo que afrontar a la prensa y sus “excesos”, como ya hemos anotado, recurrió directamente al uso de facultades extraordinarias y suspensión de garantías.

Por su parte, al hacerse cargo de la presidencia de la República, el gobierno de Porfirio Díaz se plantearía el problema de la regulación de la prensa y en 1879 circularía el rumor de que se pretendía poner otra vez en discusión la reforma del séptimo constitucional, y que lo que escondía era la intención de poner

38 El Ferrocarril (4 abr. 1872). 
límites a la libertad de imprenta. ${ }^{39}$ Pero a pesar de que la noticia fue discutida en algunos periódicos, acusando al secretario de Gobernación, Eduardo Pankhurst, de ser quien estaba detrás, la misma no tuvo mayores repercusiones. ${ }^{40}$ En realidad, al parecer ni siquiera llegó a presentarse pues el gobierno de Díaz y los tuxtepecanos carecía de la fuerza suficiente en el Congreso para lograr hacer pasar una reforma tan delicada; y porque había asuntos más urgentes que atender antes que entrar en conflictos por el tema de la imprenta y su regulación-como la reforma del artículo $78^{\circ}$ constitucional, en el que se consignaba lo relativo a la reelección de los gobernantes, además de la pacificación misma del país y de la reconciliación política con los grupos contrarios -juaristas, lerdistas e iglesistas.

Al iniciar los trabajos de la Cámara de Diputados, en una de sus primeras sesiones, la del 19 de septiembre de 1882, entre las comisiones que se formaron para atender los asuntos relevantes en materia legislativa se integró la de la Ley Orgánica del Artículo $7^{\circ}$ de la Constitución, que quedó compuesta por José Simeón Arteaga, Agustín Cerdán, Aurelio Melgarejo, y como suplente Enrique Chávarri (véase anexo 1). ${ }^{41}$ Sin embargo, como veremos a continuación, los sucesos que tuvieron lugar respecto a la reforma del mismo artículo dejaron sin efecto las labores de esta comisión, pues los cambios efectuados en su redacción hacían innecesaria la ley correspondiente, puesto que los delitos de prensa serían juzgados con base en el Código Penal.

Sería en el gobierno de Manuel González cuando, finalmente, tras tantos años y varios intentos, la reforma lograría consolidarse en 1882-1883. Se valió para ello de un cambio de estrategia, esta vez no fue en la Cámara baja sino en la alta, donde se presentó la propuesta. La aprobación de la reforma fue posible

\footnotetext{
39 Gantús, Caricatura, pp. 270, 280-281.

40 El Hijo del Trabajo (26 oct. 1879).

${ }^{41}$ DDD (19 sep. 1882).
} 
por el cambio de estrategia; especialmente porque para entonces se contaba en el Congreso con una nueva composición partidista, dominada por porfiristas y gonzalistas, que compartían un interés común en la materia y actuaron conjuntamente para alcanzarla. En efecto, en la sesión del 10 de octubre de 1882 un nutrido grupo de senadores, que representaban a los estados de Aguascalientes, Durango, Estado de México, Hidalgo, Jalisco, Michoacán, Nuevo León, Puebla y Yucatán, presentó la iniciativa, misma que fue turnada a la comisión de puntos constitucionales (véase anexo 2). ${ }^{42}$ Tras su revisión, la propuesta de reforma que salió de la Sala de Comisiones el 15 de noviembre, y que fue presentada en la sesión del día siguiente -16 de noviembre-, había sido modificada en su parte final; en lugar de "Los delitos de imprenta serán juzgados por los tribunales comunes", se proponía: "Los delitos que se cometan por medio de la imprenta serán juzgados por los tribunales competentes de la Federación o de los Estados, conforme a sus respectivas leyes". ${ }^{43}$

La reforma del artículo séptimo constitucional se presentó y discutió en la Cámara alta entre el 10 de octubre y el 27 de noviembre de 1882. En el debate participaron 11 senadores, de los cuales 8 la defendieron y 3 la rechazaron. La votación dio como resultado un total de 44 representantes a favor y sólo 3 en contra. El trámite fue mucho más expedito en la Cámara baja, recibido el proyecto el 5 de diciembre, para el día 13 fue presentado en el pleno, dándose el debate sólo en lo particular con la participación de 5 diputados, 3 de ellos a favor y 2 en contra. La reforma

42 Conformada por Jesús Lalanne, Agustín del Río, Federico Méndez Rivas, Francisco Rincón Gallardo, Víctor Pérez, Agustín R. González, Octaviano Fernández, Carlos M. Aubry, Canuto García, Darío Balandrano, Carlos Bravo, Francisco Hornedo, Pedro Hinojosa, Francisco Maldonado y Pedro Sánchez Castro. DDS, 10 de octubre de 1882.

${ }^{43}$ Los miembros de la comisión que lo firman son Enrique María Rubio e Ignacio T. Chávez. Ignacio Romero Vargas era el otro integrante, pero como no estaba de acuerdo con sus homólogos presentó un voto particular. DDS (16 nov. 1882). 
fue aprobada en esa misma sesión con 140 votos a favor y sólo 8 en contra. ${ }^{44}$

El único periódico con caricaturas que estaba en circulación durante esos meses de octubre y noviembre de 1882 era $E l$ Rasca-Tripas, pero dio cabida en sus páginas e imágenes a otros problemas, como la disputa entre el poder Ejecutivo y el Judicial, que llevó a la renuncia de Ignacio Vallarta como presidente de la Suprema Corte de Justicia, a los problemas del juego en la capital del país y a cuestiones electorales, entre otras. Al tema de la iniciativa de reforma del artículo séptimo constitucional dedicó una sola imagen el 29 de octubre. Un mes antes, sin embargo, había dedicado una caricatura a representar $\mathrm{al} 11^{\circ}$ Congreso como un buey, y a Manuel González y Porfirio Díaz como sus creadores, cuestionando así la capacidad de unos y de otros. ${ }^{45}$ La única imagen que dedicaron al asunto de la reforma fue la del 29 de octubre pero, en realidad, más que criticar el ataque a la libertad de imprenta y las restricciones y limitaciones que trataban de imponerle, la sátira se centraba en la figura de Darío Balandrano, redactor del Diario Oficial de tiempo atrás y en ese momento presidente de la mesa en la Cámara de Senadores, quien era además uno de los firmantes de la propuesta. ${ }^{46} \mathrm{~A}$ él reprochaba la caricatura el acomodarse según los vientos que soplaran, de suerte que en 1874, sirviendo al gobierno de Lerdo de Tejada desde las páginas del Diario Oficial, atacaba a los opositores y en 1882, ahora con Tuxtepec triunfante y González en la presidencia, apoyaba las medidas contra la prensa misma para congraciarse con el Ejecutivo federal.

44 DDS (27 nov. 1882); DDD (13 dic. 1882). Sobre el tema de la reforma del artículo séptimo constitucional remitimos a GANTús, Caricatura, pp. 279-312. Ahí se analizan las participaciones, posicionamientos e intervenciones de los senadores y diputados.

45 “Y lo hicieron a su imagen y semejanza”, El Rasca-Tripas (24 sep. 1882). Esa caricatura se analiza en GANTús, Caricatura, pp. 285-287.

46 “Senado", El Rasca-Tripas (29 oct. 1882). GANTús, Caricatura, pp. 290-292. 
Finalmente, tras la aprobación de la reforma por ambas Cámaras, y de las legislaturas estatales, fue dada a conocer por decreto del Ejecutivo federal el 15 de mayo de 1883 (véase anexo 2). Dos cambios importantes supuso la reforma: la supresión del jurado popular y la autorización para que los delitos de imprenta fueran juzgados de acuerdo con los códigos penales y no por una ley orgánica, por lo que la elaboración de la misma, a la que aludíamos antes, ya no fue necesaria. Quedaba así suprimido el fuero de la prensa, dejando a los periodistas sujetos a los tribunales del orden común. Y, aún más, quedaban los delitos de imprenta sujetos a las leyes penales. Ello suponía, por supuesto, un endurecimiento en los procedimientos y las condenas.

\section{UN GOBIERNO SIN FACULTADES EXTRAORDINARIAS}

Y LOS EXTRAORDINARIOS SUCESOS CONTRA LA PRENSA

En una escena de teatro de títeres se muestra a varias marionetas masculinas vestidas de charros que portan diversas armas, desde palos y cuchillos hasta sables y pistolas y que causan un gran alboroto y destrucción en la "Imprenta Políglota”, según acusa un letrero que sitúa el lugar en que ocurren los hechos. Uno de ellos ataca una especie de vitrina haciendo añicos los cristales; otro se ocupa de desgarrar los ejemplares de un impreso; hacia el fondo todo es confusión. En el plano central se muestra a una de aquellas marionetas abriendo fuego contra uno de los trabajadores de la imprenta, quien cae abatido por la violencia del impacto de la bala. Por el suelo se ve a otra persona totalmente desvanecida y una más parece intentar esconderse para ponerse a salvo del ataque. También se ven periódicos, cajas y otros instrumentos desperdigados por el piso. En la parte superior del escenario, tras bambalinas, asoman varias manos que sostienen los hilos con los que se mueve a las marionetas. Los puños del vestuario de un par de esas manos revelan que se trata de un traje militar de gala, sugiriendo así la presencia del propio general 
Díaz detrás del suceso, estrategia para denunciar a las autoridades nacionales como las orquestadoras del ataque (caricatura 5).

Ése era el rumor que circulaba por las calles y las plazas y se reproducía de manera velada o franca en las páginas de los periódicos: que las agresiones desplegadas contra integrantes del mundo de la prensa provenían de las más altas esferas del poder político. La imagen de La Casera da cuenta del ataque a La Políglota, sin duda el más feroz y de mayores consecuencias, que llegó a las páginas de prácticamente todos los periódicos del momento. ${ }^{47}$ En afecto, a mediados del mes de febrero de 1880, el día 14 , asaltaron las instalaciones de la imprenta, donde se editaba, desde hacía apenas unas semanas, El Republicano, periódico crítico del gobierno. Según dan cuenta las notas de prensa, esa noche un grupo de aproximadamente 20 individuos, "forajidos" los llama La Casera, cerca de las 19:30 horas entraron disparando y destruyeron todo lo que encontraron..$^{48} \mathrm{El}$ saldo de tal acción, además de la destrucción de maquinaria, fue el de algunos heridos y un muerto. Si bien el ataque en sí mismo ya resultaba singular, lo verdaderamente incomprensible era que: "Los asaltantes no robaron absolutamente nada, contentándose con romper la prensa, desbaratar las formas del Republicano y despedazar las cajas y peinazos y los tipos de la imprenta". ${ }^{49}$

La escena, aun en los trazos sencillos de la representación visual, es dramática: la violencia física cobra toda su fuerza para acabar con los trabajadores de la imprenta. Y no es necesario darle vueltas a lo que con tal acción se pretendía: acallar a los opositores y críticos de las autoridades. Para que no haya

\footnotetext{
47 “¡Asalto a mano armada! ¡Veinte hombres asesinan a los impresores de nuestro periódico, rompen las prensas y destruyen todos los útiles del establecimiento! [...]" El Monitor Republicano (17 feb. 1880). Reproduce párrafo de El Republicano (15 feb. 1880).

${ }^{48}$ La Casera (22 feb. 1880).

49 El Monitor Republicano (17 feb. 1880). Reproduce párrafo de El Republicano (15 feb. 1880).
} 


\section{Caricatura 5}

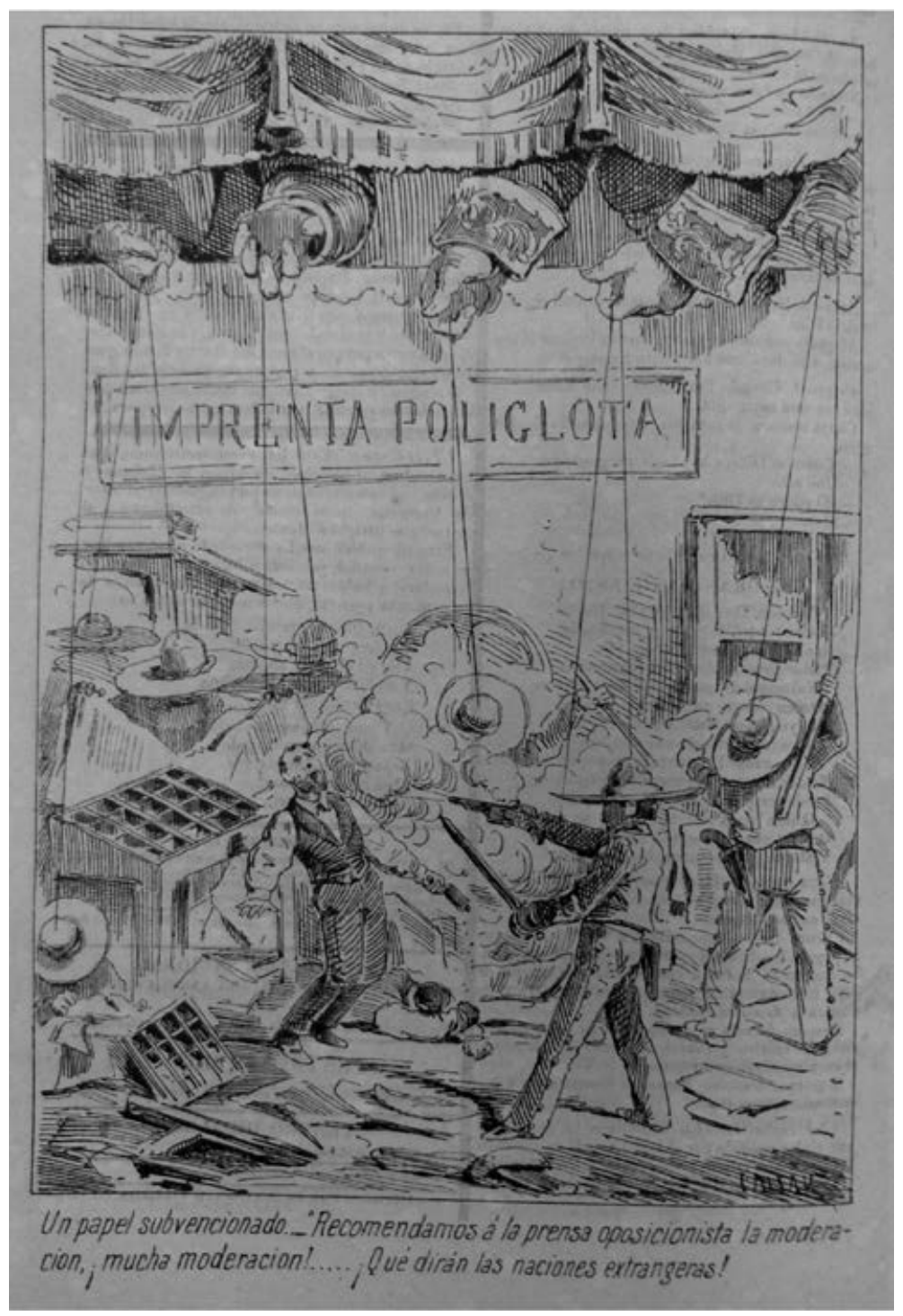

“Un papel subvencionado”, La Casera (22 feb. 1880). 
duda, la leyenda que complementa la imagen reza: "Un papel subvencionado. 'Recomendamos a la prensa oposicionista la moderación, ¡mucha moderación!... ¡Qué dirán las naciones extrangeras [sic]!" La ironía es evidente, la preocupación del gobierno por la opinión que sobre su actuación pudieran formarse en el exterior a partir de las notas de los periódicos críticos los lleva a "patrocinar" acciones que resultan mucho más reprobables, tanto en el propio país como en el extranjero. En particular preocupaba al gobierno silenciar a sus críticos ante la visita del general Ulises Grant, expresidente de los Estados Unidos, que arribó al país el 18 de febrero.

El Monitor Republicano anotó en su gacetilla: "El sábado en la noche ha sido asaltada la imprenta en que se publica El Republicano, pero con condiciones tales, con tal lujo de audacia, que desde luego hace nacer la vehemente sospecha de que los malhechores, o los bravos, se consideraban apoyados por la autoridad". ${ }^{50}$ Las oficinas de El Republicano habían sido visitadas apenas unas semanas antes por un policía que recogió los ejemplares de la edición del 29 de enero argumentando para ello la existencia de una denuncia por difamación que se había presentado en su contra. ${ }^{51}$ Lo que encontramos de mayor interés en el periódico de la fecha es un artículo de la sección editorial titulado "Dos ministros" en el que se aludía a la "crisis ministerial", que incluía a las secretarías de gobernación y hacienda, y se criticaba a varios personajes que se suponía podían suplir a quienes en el momento ocupaban esas carteras. Pero la denuncia fue hecha por un párrafo titulado "Voló el pájaro", que trataba sobre un español que supuestamente había cometido desfalco y huido. Tras celebrarse el juicio correspondiente el periódico fue absuelto. ${ }^{52}$

\footnotetext{
50 El Monitor Republicano (17 feb. 1880).

51 El Republicano (5 feb. 1880).

52 El Republicano (5 feb. 1880).
} 
El asalto a la imprenta La Políglota, que dejó heridos y un muerto como saldo, fue el más llamativo, violento y extraordinario suceso contra la prensa y sus integrantes, pero no fue el único. Para un sector de la prensa la suma de ataques no era más que la puesta en práctica de una política que perseguía poner freno a la libertad de imprenta y de expresión. Esa política, consideramos, escondía el temor de las autoridades de ser expuestas en sus errores, debilidades y vicios o, simplemente, era el recurso último mostrado ante la falta de capacidad para enfrentar y responder a la crítica con los mismos medios. Y en efecto, lo era. Desde el arribo de los tuxtepecanos al poder la política de control sobre la prensa se endureció; primero por medio de la presión legal y después, cuando sintieron que la primera no rendía los frutos que esperaban, se valieron de la represión extralegal.53

En los primeros años de gobierno tuxtepecano, bajo la presidencia de Díaz, 1877-1878, el gobierno recurrió a la detención de periodistas por distintas causas y se siguieron procesos legales contra varios miembros de la prensa. ${ }^{54}$ También, según notas de la época, siempre en el marco normativo, se valieron de la confiscación de imprentas para silenciar a la prensa; tal fue el caso de El Pájaro Verde en 1878. ${ }^{55}$ Pero para 1879, y los años subsecuentes, la violencia mutó, pasando de la aplicación de la estrategia de control en el marco de la justicia, fueran las denuncias justificadas o no, a otra forma de violencia, ya no legal sino física. Amenazas e intimidación padecieron los redactores de El Proteccionista, quienes informaron que habían recibido un

${ }^{53}$ Las denuncias contra la prensa a lo largo del siglo xIx, incluido el periodo que aquí estudiamos, han sido sistematizadas por CHávez Lomelí, Público, pp. 303-334.

${ }^{54}$ En 1877 fueron detenidos Jorge Ainslie, José Vicente Villada, Agustín R. González y Alfredo Bablot y se siguió proceso contra los periódicos El Federalista y La Sombra de Lizardi, entre otros. GANTús, Caricatura, pp. 271-272. Véase también Chávez Lomelí, Público, p. 327.

55 Y de la imprenta del periódico La Voz de Yucatán, ambas ocurridas en 1878. La Libertad (4 ene. 1879). 
anónimo avisándoles que contra ellos se preparaba un ataque como el que había sufrido un colega suyo, Gerardo Silva, hacía muy poco. ${ }^{56}$ Éste, Silva, quien se desempeñaba como redactor de La Libertad, había sido asaltado por individuos que vestían chalecos militares, acusaba El Tranchete. ${ }^{57}$ Según dichos del momento, ese periodista se oponía a la candidatura de Manuel González. También Arcadio Cabrera, quien era el editor de La Voz de Anábuac, y había sido dos años antes responsable de La Gaceta de Holanda, fue asaltado en su propia casa, aunque el hecho fue achacado a la delincuencia común. ${ }^{58}$

Además de la agresión directa y personal, la otra estrategia para poner freno a la libertad de expresión, como ya apuntábamos, fue la intimidación mediante el ataque a las oficinas de los periódicos y a las imprentas. Unos pocos meses más tarde de los sucesos de La Políglota, en mayo de 1880, la oficina de El Socialista fue agredida en medio de la noche por un grupo de individuos que apedrearon los cristales. Los delincuentes se dieron a la huida, pero algunos de los trabajadores que salieron a defenderse lograron atrapar a dos de ellos y los entregaron a la policía. Hasta ahí todo podría ser leído como simple vandalismo, pero lo extraño ocurrió a la mañana siguiente: cuando los representantes del periódico se presentaron a levantar la denuncia los asaltantes habían sido liberados. Las autoridades adujeron que al no presentarse nadie a las nueve de la mañana a denunciar tuvieron que liberarlos. ${ }^{59}$ La situación de inquietud e indefensión en que se encontraban los miembros de la prensa llevó a los redactores de uno de los impresos a declarar: "Los repetidos atentados de que están siendo víctimas los miembros de la prensa, y aún los más oscuros operarios de ella; la sospecha vehemente de que esos hechos escandalosos proceden de la

\footnotetext{
56 El Hijo del Trabajo (4 mayo 1879).

57 El Tranchete, hoja suelta. Alcance al número 3 (abr.-mayo 1879).

58 El Libre Sufragio (13 dic. 1879).

59 El Hijo del Trabajo (23 mayo 1880).
} 
autoridad, en cuyas regiones se organizan -según la fama asegura- $[\ldots]$ nos obliga a levantar la voz de manera enérgica a la faz de la Nación entera".$^{60} \mathrm{Y}$ orilló también a otro tipo de acciones por parte de los periodistas como respuesta, como veremos a continuación.

Con un día de diferencia dos periódicos satíricos, El Padre Cobos y La Casera, se ocuparon de dar representación desde la sátira visual a un hecho insólito... Parapetados detrás de una endeble cerco defensivo, frente a las puertas de la "Imprenta de La Patria”, se ve a Ireneo Paz, editor y propietario del diario, que sostiene una especie de bastón de mando, a un par de escritores, como lo denotan las gigantescas plumas que llevan sobre los hombros, y a un amplio grupo de operarios de la imprenta armados con rifles y pistolas. La misma escena, esto es, los redactores y trabajadores de imprentas y periódicos, armados y expectantes aguardando a las puertas de sus cuarteles, se repite en El Combate y en la Imprenta Políglota. Todos ellos están dispuestos a arriesgar sus vidas para defender la "libertad de imprenta". Con las armas en las manos, aguardan la llegada de los enemigos que, ocultos y comandados por un policía, esperan a corta distancia la señal para lanzarse al ataque (caricatura 6). La otra escena ocurre frente a la Imprenta de La Patria: en ella un grupo de gendarmes de la policía huyen asustados ante la defensa que hace de las instalaciones un joven operario de la imprenta, que en la representación es apenas un niño, que solo, pero en actitud firme, dispara una pistola. El suceso es observado por un gran contingente integrado por personas de diferentes estratos sociales que muestran una actitud complacida; esa escena refiere a un suceso ocurrido unos días antes. ${ }^{61}$

Por su parte, La Casera mostró a las "Oficinas de La Patria” convertidas en un verdadero "campamento" militar y a los

60 La Patria (21 mar. 1880).

61 El Padre Cobos (27 mar. 1880), “Asalto a la Patria”. 


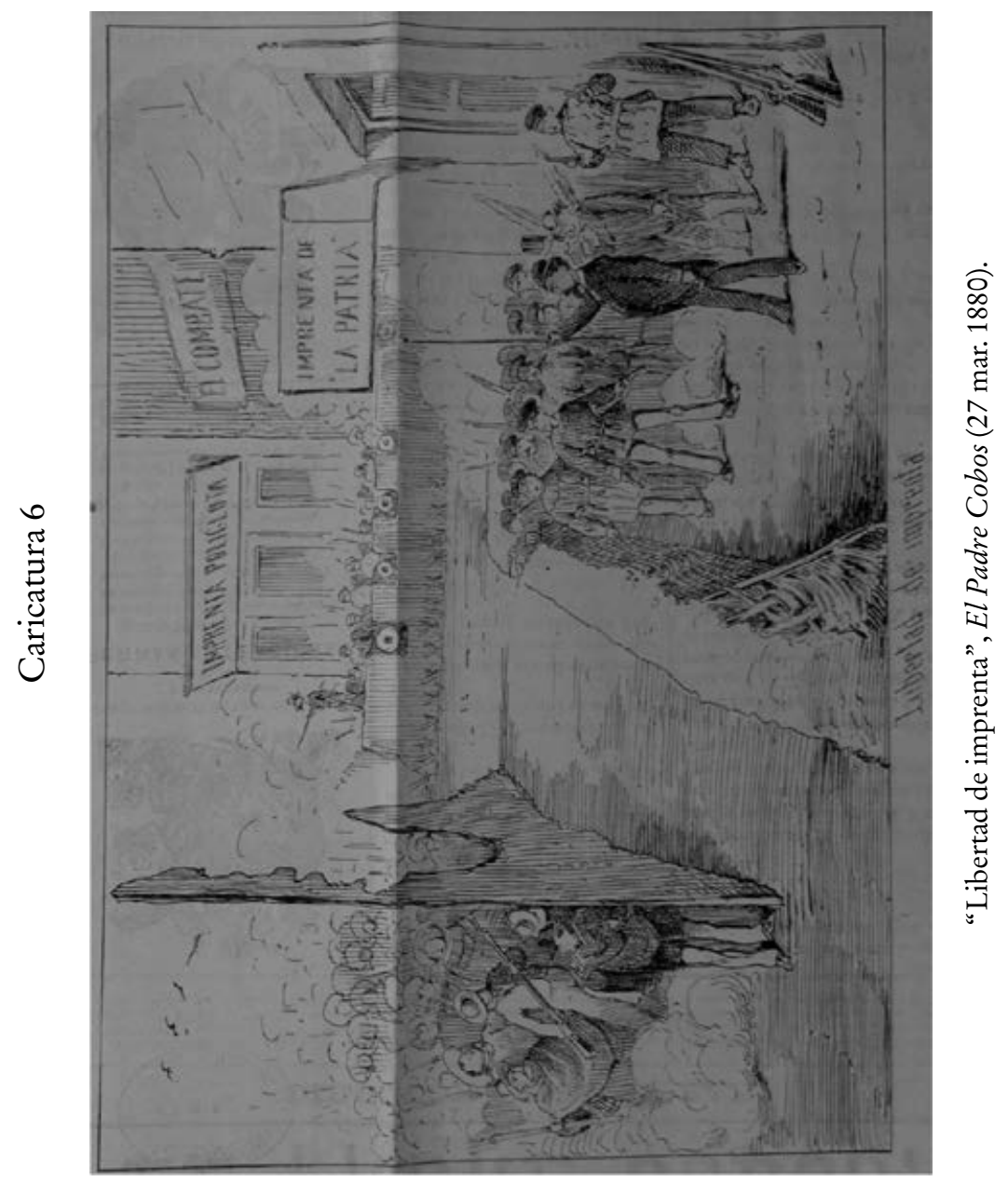


integrantes del equipo de redacción y los operarios transformados en soldados armados con fusiles con bayonetas. Su propietario, Ireneo Paz, es el comandante en jefe de esas fuerzas, cuyo traje está hecho de las páginas del periódico y necesita apoyarse en las armas para sostenerse y poder defender la actividad periodística y la libertad de imprenta. El parapeto detrás del cual se resguarda el ejército de escritores e impresores está hecho también, como el traje de Paz, de las páginas del periódico (caricatura 7).

Si extraordinarios son los sucesos de ataques, agresiones e intimidaciones contra la prensa achacados a las autoridades, excepcional resulta el hecho de que una imprenta se convierta en un fuerte y sus inmediaciones en un campo de batalla... reales y no sólo discursivos. En efecto, el conjunto de las tres imágenes da cuenta de los sucesos, por un lado, y de la batalla que en términos físicos y periodísticos estaba teniendo lugar. Era un hecho real que Ireneo Paz había procedido a adquirir armas para la defensa de su empresa y su personal: "Los impresores y redactores del periódico La Patria, se han armado con cincuenta Remingtons y cinco mil tiros". 62

El mismo Paz lo explicaría en las páginas de su diario:

Cuando el primero de quien la voz pública nos dice que debemos desconfiar, es el Gobierno, no nos queda más recurso que buscarnos por nosotros mismos lo que las autoridades parecen ser impotentes para darnos: la seguridad de nuestras vidas [...] En tal virtud, nuestras oficinas son desde hoy un campamento. Todos los jefes y dependientes de nuestro diario trabajan con el arma al lado y la canana al cinto. ${ }^{63}$

Esta acción de armarse era la respuesta, podemos estimar que desesperada, de los redactores de La Patria ante el

62 La Casera (28 mar. 1880).

63 La Patria (21 mar. 1880). 


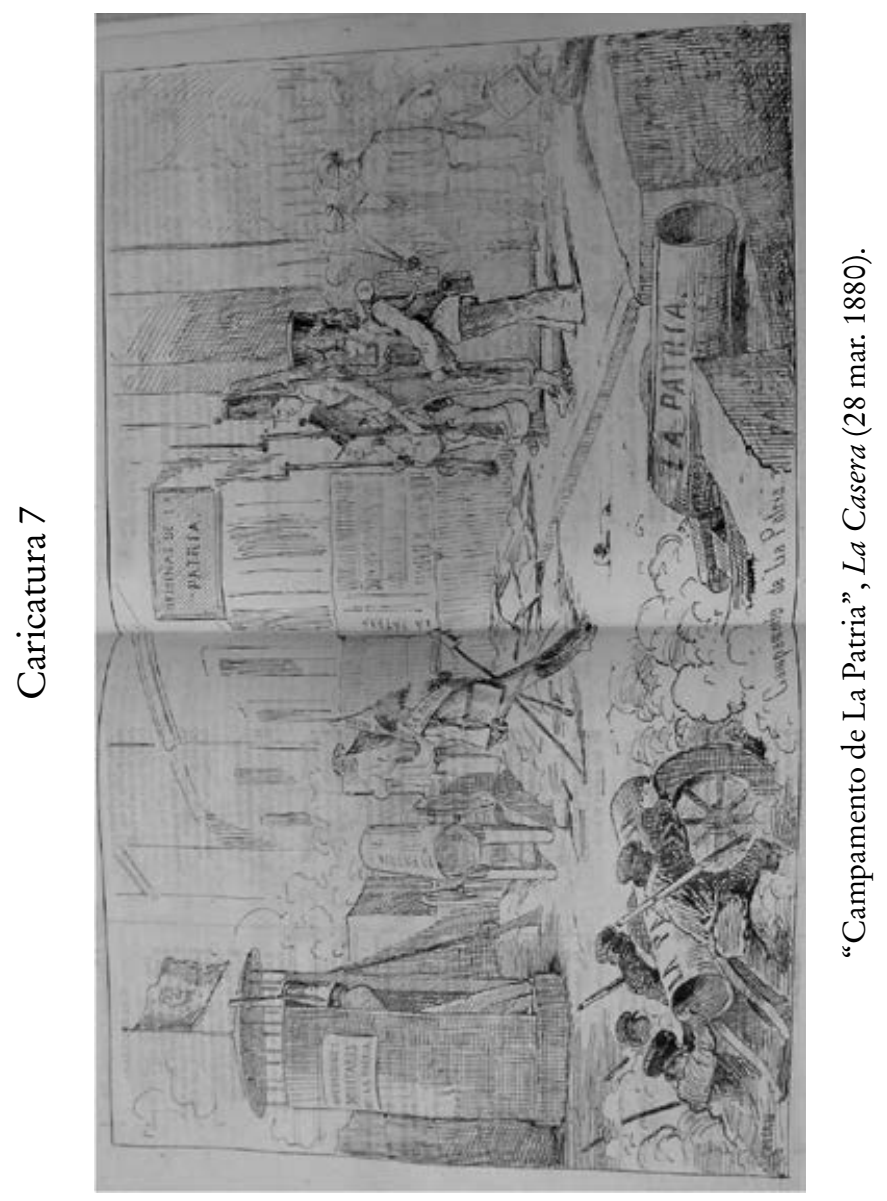


atentado que el 18 de marzo de 1880 sufrió Manuel Caballero, quien era redactor del periódico, y que acusaba haber sido "víctima de una tentativa de asesinato" al salir de la imprenta El Socialista, perpetrada por un individuo a quien desconocía. Los tiros disparados por el agresor no lastimaron a Caballero, pero los agresores sí hirieron a golpes a un joven dependiente de la imprenta de apellido Pruneda, quien intentaba ayudar a Caballero. Ambos, al presentarse a denunciar, fueron apresados en tanto los agresores fueron liberados, según narraba el propio periodista en su carta enviada a la redacción de La Patria ${ }^{64}$

¿Por qué todos esos ataques contra los integrantes de la prensa y de sus instalaciones? ${ }^{65} \mathrm{El}$ gobierno de Díaz no pudo ser exhibido por los miembros de la prensa por el uso de facultades extraordinarias contra la libertad de expresión, ni se pudieron mofar de que hubiera intentado la reforma del artículo séptimo constitucional, porque ni logró obtener las primeras ni intentó siquiera promover la segunda, cuya pretensión no pasó de un rumor. A diferencia de los gobiernos que le precedieron,

${ }^{64}$ Ese suceso estaba ligado a otro, el cual el mismo periódico La Patria había sufrido y del que daba cuenta: que su redactor en jefe había sido avisado que el periódico estaba siendo vigilado por cuatro individuos comandados por Cástulo Zenteno, quienes estaban apostados en la esquina de la Imprenta de La Patria. Al llegar escuchó unos disparos, los del ataque a Caballero, en el que denunciaba estuvo involucrado un general llamado Carlos Villegas. La Patria (19 mar. 1880).

65 Para 1880, además del control de la prensa tan anhelado por el gobierno y la lucha por preservar la libertad de expresión por parte del periodismo crítico, el estado de agitación que recorría el país estaba también ligado al enfrentamiento encarnecido por la cuestión electoral centrada en la sucesión presidencial. El periódico de Ireneo Paz apoyaba la candidatura de Trinidad García de la Cadena y hacía una guerra franca a los gonzalistas. Además, era un periódico que, según señalaban otros impresos, se había destacado por sus ataques al gobierno. El Monitor Republicano (17 feb. 1880). Aunque Paz apoyó la revolución tuxtepecana y fue un aliado consistente de Díaz a lo largo de todo su gobierno, en esta coyuntura electoral tomó distancia de él pues no coincidían en sus filiaciones político personalistas. 
los de Juárez y Lerdo de Tejada, el de Porfirio Díaz (1877-1880) no usó facultades extraordinarias contra la prensa. Pero no lo hizo no porque no lo deseara y hasta lo solicitara sino porque el Congreso de la Unión no autorizó tales prerrogativas ya que no existía estado de excepción que justificara la solicitud del Ejecutivo. La intención de reformar el séptimo constitucional también rondó en el ambiente, pero el grupo llegado al poder con la revolución tuxtepecana no contaba con la fuerza para lograr que fuera aprobada por el Congreso, por lo que ni siquiera se intentó. En cambio, su administración fue responsabilizada, velada y abiertamente, por diversos órganos de la prensa, incluyendo algunos muy cercanos al régimen, de los atentados violentos ocurridos durante su periodo presidencial contra el universo periodístico. Fuera cierto o no, porque quizá no lo fue en todos los casos - pues no hay que descartar los enfrentamientos entre los propios miembros del gremio, así como los ataques perpetrados por algún ofendido y, aún, los casos provocados por la delincuencia común-, la opinión general era que las autoridades se encontraban involucradas en tales hechos, y algún periodista señaló que se trataba de "una cruzada contra la libertad de imprenta". ${ }^{66}$

Aunque haría falta un estudio minucioso que siguiera el rastro de todos los ataques violentos perpetrados contra la prensa entre 1876 y 1883, el número de denuncias dadas a conocer a través de las páginas de los propios impresos dejan ver que esos años hubo una significativa presencia de ataques de diversos tipos que incluían desde la agresión directa a las personas hasta el asalto y destrucción de las imprentas, desde las amenazas y los golpes hasta el asesinato. Todos esos actos se hicieron parecer como producto de la delincuencia, pero, según la opinión de diversos actores de la época, en realidad quienes estaban detrás de tales sucesos eran las autoridades que buscaban así amedrentar el

${ }_{66}$ El Republicano (22 feb. 1880). 
ánimo de los integrantes de la prensa, en particular de quienes se oponían de alguna forma a las políticas gubernamentales.

Lo que podemos ver y proponer es que, ante la falta de mecanismos legales que, a conveniencia, les permitieran controlar las acciones de la prensa, Díaz y sus allegados políticos se valían de la violencia para dañar y amedrentar a quienes se les oponían. En efecto, durante estos años el gobierno desplegó una política de control desde dos flancos. Por un lado, se instrumentó una estrategia consistente en entablar demandas penales por quienes se sentían directamente agraviados, tanto funcionarios de todos los niveles, en ocasiones las propias corporaciones -como sucedió con el ayuntamiento de la ciudad de México-, como por ciudadanos comunes. Pero solía suceder que en los procesos legales los jurados populares absolvieran a los denunciados, causando así el enojo y la frustración de las autoridades. Por el otro, se recurrió al uso de la violencia en diversos niveles, orquestada por las autoridades, pero ejecutada de forma encubierta, escudándose en la delincuencia. Esta doble táctica para controlar, limitar y amedrentar a la prensa sería continuada en el gobierno de Manuel González (1880-1884), al menos hasta 1883, cuando se logró la reforma del artículo séptimo constitucional que, ya sin la figura del jurado popular, permitió hacer de la estrategia legal el camino para imponerse al periodismo.

A partir de lo que observamos en éste y otros estudios sobre la materia, podemos sostener que, en los años anteriores, en los que gobernaron Juárez y Lerdo, y después de la reforma del artículo séptimo constitucional efectuada en 1882-1883, los ataques violentos fueron ocasionales, cuando los hubieron, porque si bien se trataba de contener y reprimir a la prensa, se hacía en el marco de la ley, aunque fuera valiéndose de artimañas y estratagemas. En cambio, durante los periodos presidenciales de Díaz, el primero en su caso, y de González, se multiplicaron las agresiones, sin prescindir, por otra parte, de los procedimientos legales; esto es, hubo un doble frente de ataque a la prensa. 
La censura, los límites, la represión contra la libertad de prensa y de expresión fueron algunos de los temas expuestos en la caricatura política de la época en estudio. Las representaciones dan cuenta de los derroteros y vicisitudes para controlar y defender a la libertad de imprenta, la que tenía varios enemigos poderosos, entre ellos las facultades extraordinarias, la suspensión de garantías, la reforma del artículo séptimo constitucional, la cárcel de Belén, la represión, los ataques violentos y las ambiciones de poder de las autoridades -particularmente del presidente en turno-, como se mostraba en muchas de las sátiras visuales.

Como hemos mostrado, el periodo en estudio, 1868-1883, fue el de la búsqueda de una regulación más estricta sobre la prensa por parte de las autoridades y el de la resistencia por algunos miembros del mundo del periodismo. Estuvo marcado por el uso de facultades extraordinarias y la suspensión de garantías durante los periodos convulsos, en los que imperaron las revueltas y los pronunciamientos, pues fueron esas las medidas con las que el gobierno pretendió frenar a una prensa que cuando no contribuía abiertamente, al menos apoyaba, aunque fuera de manera solapada, a quienes estaban contra el régimen constitucional, como ocurrió en 1871 y 1876, cuando tuvieron lugar los pronunciamientos de La Noria y de Tuxtepec y los presidentes, Juárez y Lerdo de Tejada, respectivamente, acudieron a ellas. Pero también comprende los años en que al uso del marco regulatorio se sumaron las estrategias represivas extralegales, en las que los ataques físicos contra periodistas o imprentas fueron los signos más evidentes de la desesperación de un gobierno incapaz de encontrar medios de hacer frente al periodismo opositor.

Pero si facultades extraordinarias y suspensión de garantías fueron comunes entre 1867 y 1876 , todo el periodo, en cambio, estuvo marcado por los intentos para modificar las condiciones 
constitucionales que, consideraba el gobierno, favorecían al periodismo "insidioso", esto es, por lograr la reforma del artículo séptimo de la Constitución. La reforma supuso un largo camino, marcado por las voces a favor y en contra, por los debates en la prensa misma y en la cámara; finalmente, tras más de quince años, el artículo sería reformado de manera que la prensa perdió su fuero. Si antes de 1883 la mayoría de los procesos seguidos contra los impresos y sus redactores fueron ganados por éstos, a partir de entonces, con la reforma, prácticamente en todos serían encontrados culpables. El cambio constitucional dio a las autoridades un instrumento muy efectivo para controlar a la prensa, por lo que la violencia física que, como mostramos, se había desplegado entre 1877 y 1882, disminuyó significativamente, apareciendo posteriormente sólo de manera esporádica.

La libertad de imprenta fue, pues, un tema relevante tanto para el gobierno en turno como para los integrantes de la prensa. Y, a pesar de que se pudiera considerar como escasa o insuficiente la atención que la crítica satírico visual le prestó al asunto, a su denuncia o tratamiento, en función del bajo número de caricaturas dedicadas al tema, siendo el asunto de la legislación vital para la existencia misma, o para la forma de esa existencia, de los periódicos, ello no fue exactamente así. Como hemos procurado dejar en evidencia y fundamentar a lo largo de estas páginas, los factores explicativos de tal situación son varios. Primero, hay que considerar el reducido número de impresos de este carácter -el promedio de periódicos con caricaturas por año fue de dos-, y la inexistencia, en ocasiones, de los mismos en momentos álgidos de la materia, pues muchos de ellos estuvieron en circulación apenas unos meses. Segundo, a lo anterior hay que sumar que en su mayoría esos impresos eran semanarios y que incluían sólo una caricatura por número, siendo pocos los que tenían dos o tres y menos aún los que llegaban a cuatro. Tercero, siendo semanarios, en sus representaciones visuales tenían que atenderse diversos 
temas de la vida pública y solían tener que privilegiar uno o dos de los principales sucesos de la semana. Cuarto, no hay que perder de vista que muchos de los periódicos satíricos con caricaturas fueron impresos de coyuntura, esto es, nacían con un fin determinado, muchos de ellos con propósitos electorales, y se centraban en alcanzar sus objetivos.

Pese a las limitantes, pese al aparente bajo número de imágenes dedicadas al tema, como hemos procurado mostrar a lo largo de estas páginas, las representaciones de la sátira visual permiten seguir el itinerario de la legislación y de algunas prácticas respecto a la libertad de imprenta y en ellas podemos observar la forma en que se construyó un discurso que presentó a las autoridades y sus medidas como una constante amenaza contra la prensa y a ésta como un débil ser reprimido y vejado por las primeras. Cuando se trató de la libertad de imprenta los caricaturistas, los periódicos en que se publicaban y las representaciones que elaboraron no hicieron, en lo general, distingos entre la prensa oficial y la independiente, como sí sucedía en otros casos, en los que el ataque mutuo signaba los contenidos. Ello era así, muy probablemente, porque las medidas regulatorias y normativas, en términos de ley, que no de la práctica de esa ley, afectaban a todos.

En algunos momentos la representación de la imprenta como víctima pudo ser una estrategia para desacreditar a las autoridades; en otros, fue expresión de una genuina preocupación por el derrotero que seguiría la prensa al instrumentarse ciertas medidas legales. Para la cabal comprensión del tema de las relaciones entre la prensa y el gobierno, así como del papel que desempeña la implementación de regulaciones legales y las diversas estrategias extralegales desplegadas para su control por éste último, aún son necesarios estudios que pongan atención a los discursos elaborado por unos y otros actores, y que den seguimiento a las prácticas en torno a la libertad de imprenta para poder responder preguntas tales como si era el gobierno 
quien por su temor a que la prensa criticara sus acciones desplegaba una política represora, o si era la prensa -cierto sector de ella- la que con su proceder obligaba a las autoridades a actuar en su contra, dictando para ello leyes restrictivas y, en ocasiones, transgrediendo los márgenes de la legalidad. ${ }^{67}$ La tarea en esta materia es aún ardua.

${ }^{67}$ En similar sentido, hay que tener presente el debate dentro del propio gremio periodístico sobre lo que era éticamente -moral, en términos de la épocaaceptable y lo que era reprobable en la realización del oficio, sobre los derechos y los límites que debían regir la práctica de su actividad y sobre la calidad moral de sus miembros. Sobre el tema, Gantús, "Gobierno”, pp. 245-275. 


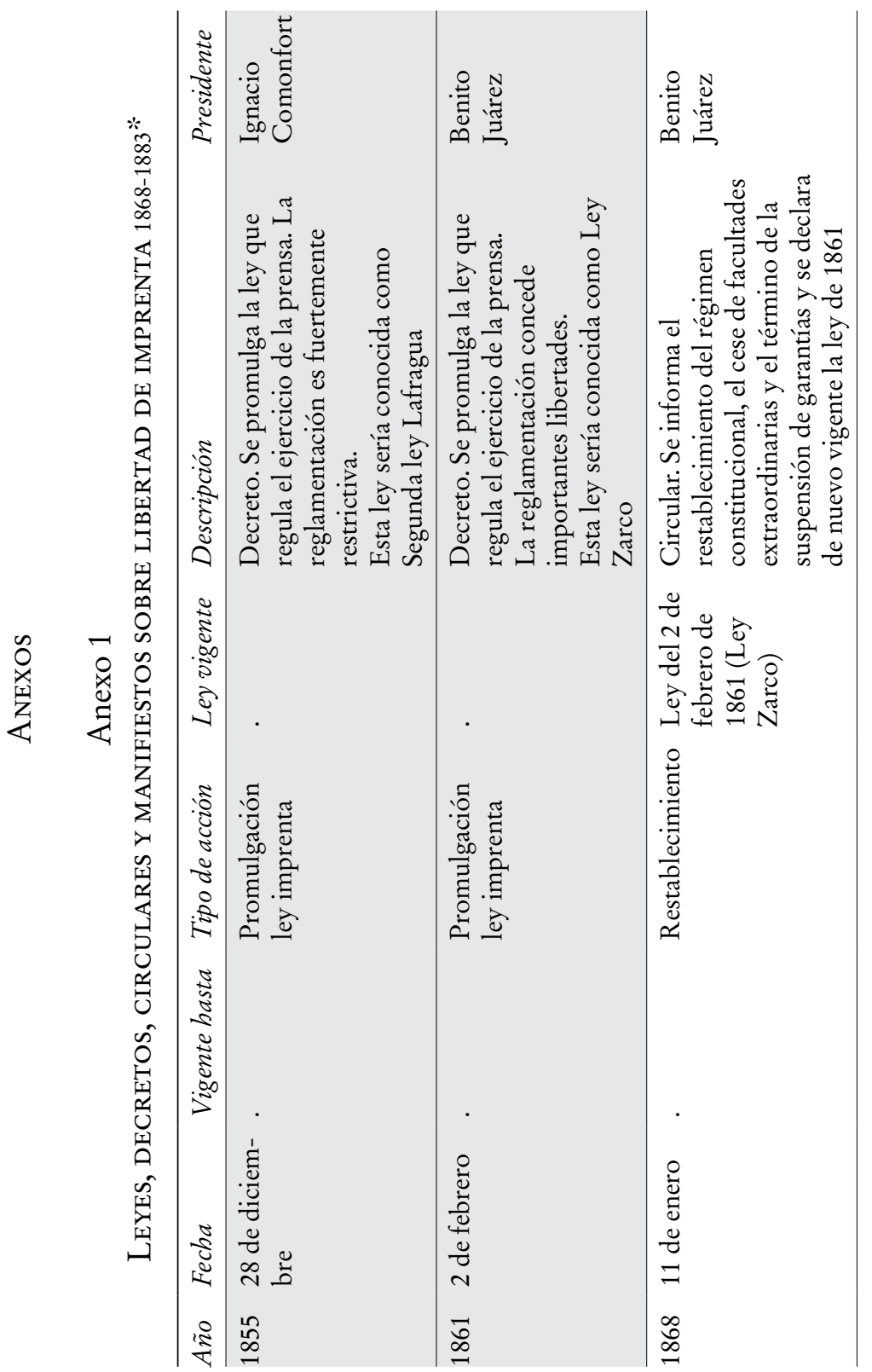




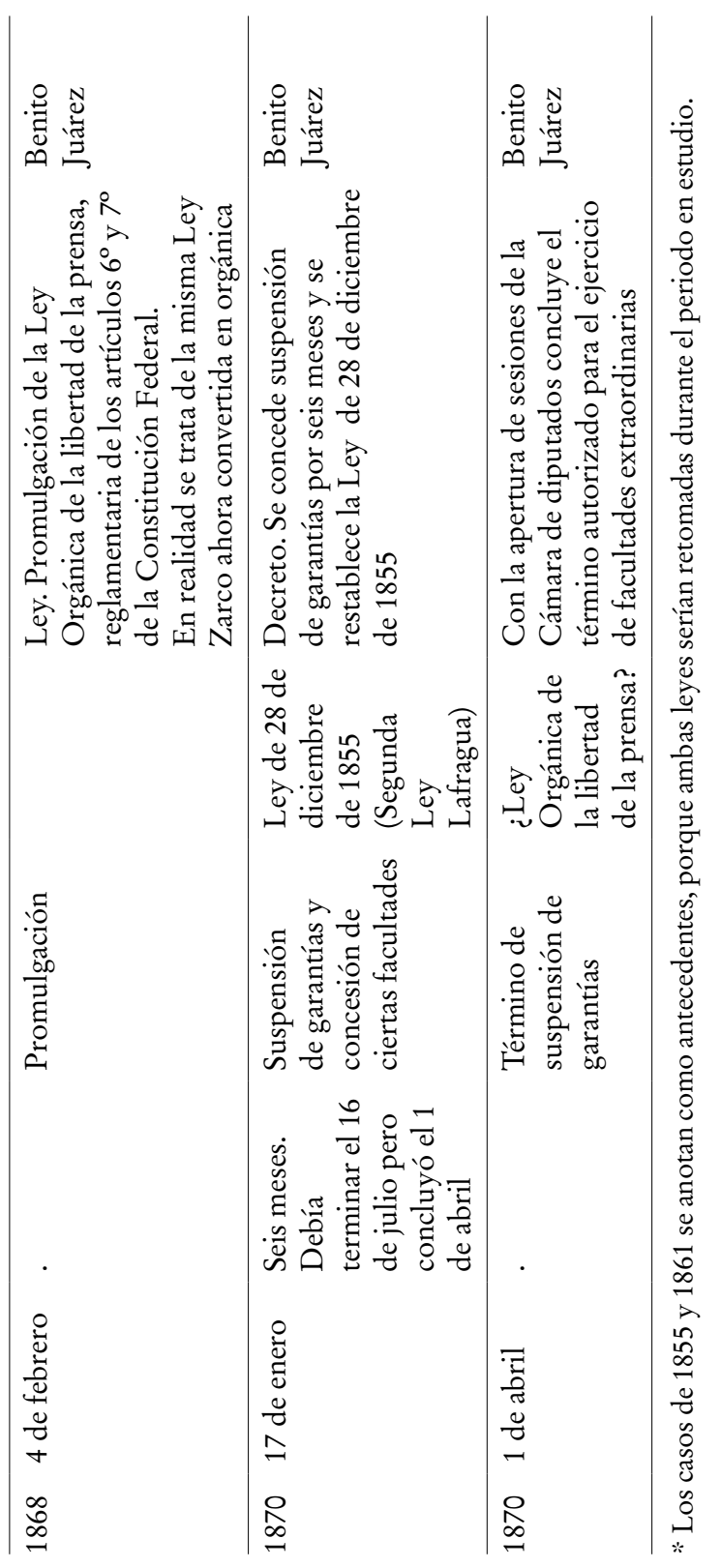




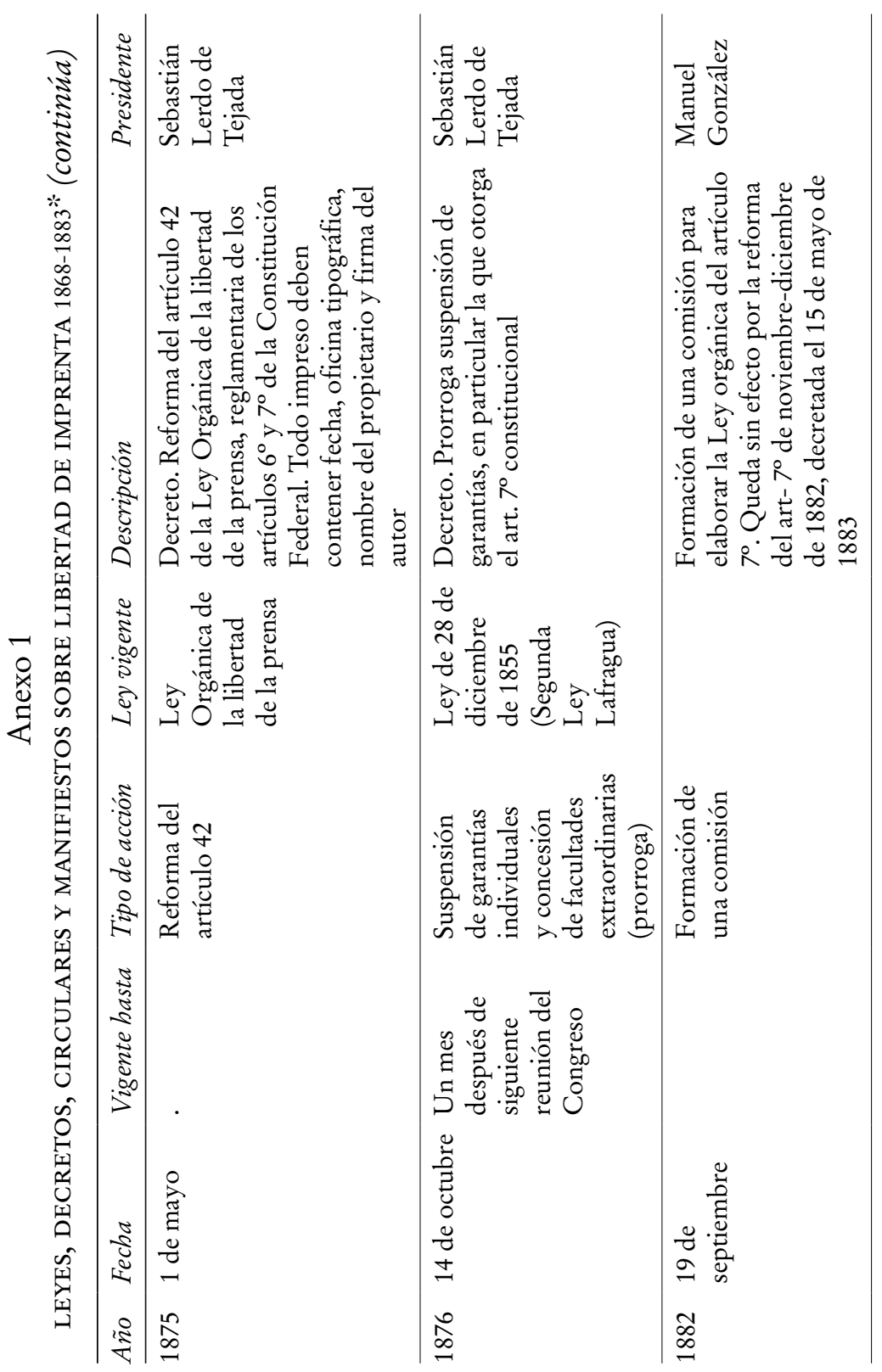




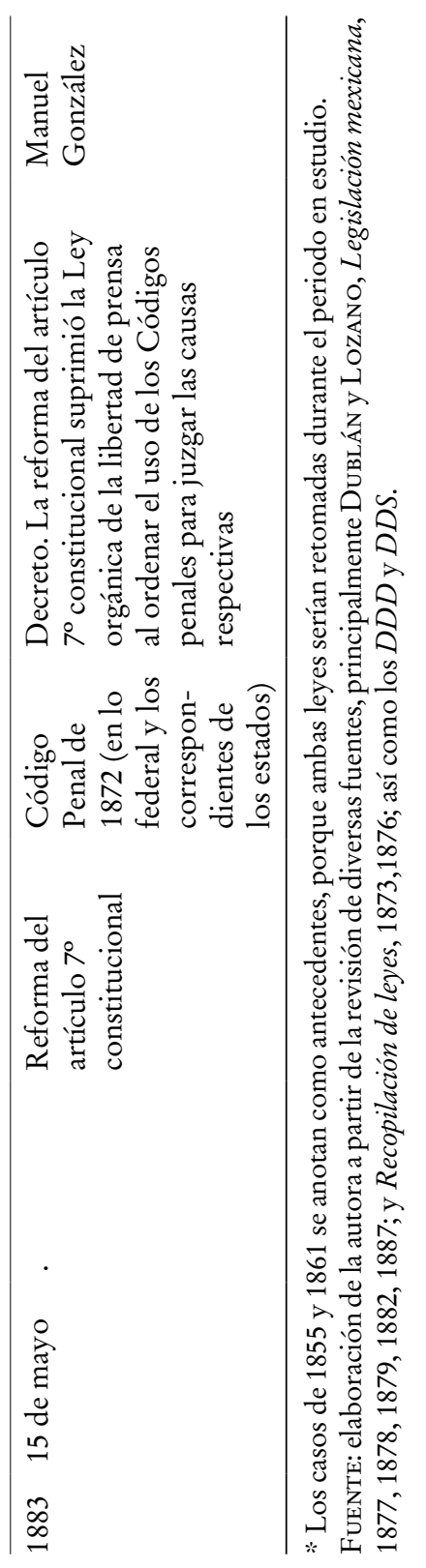




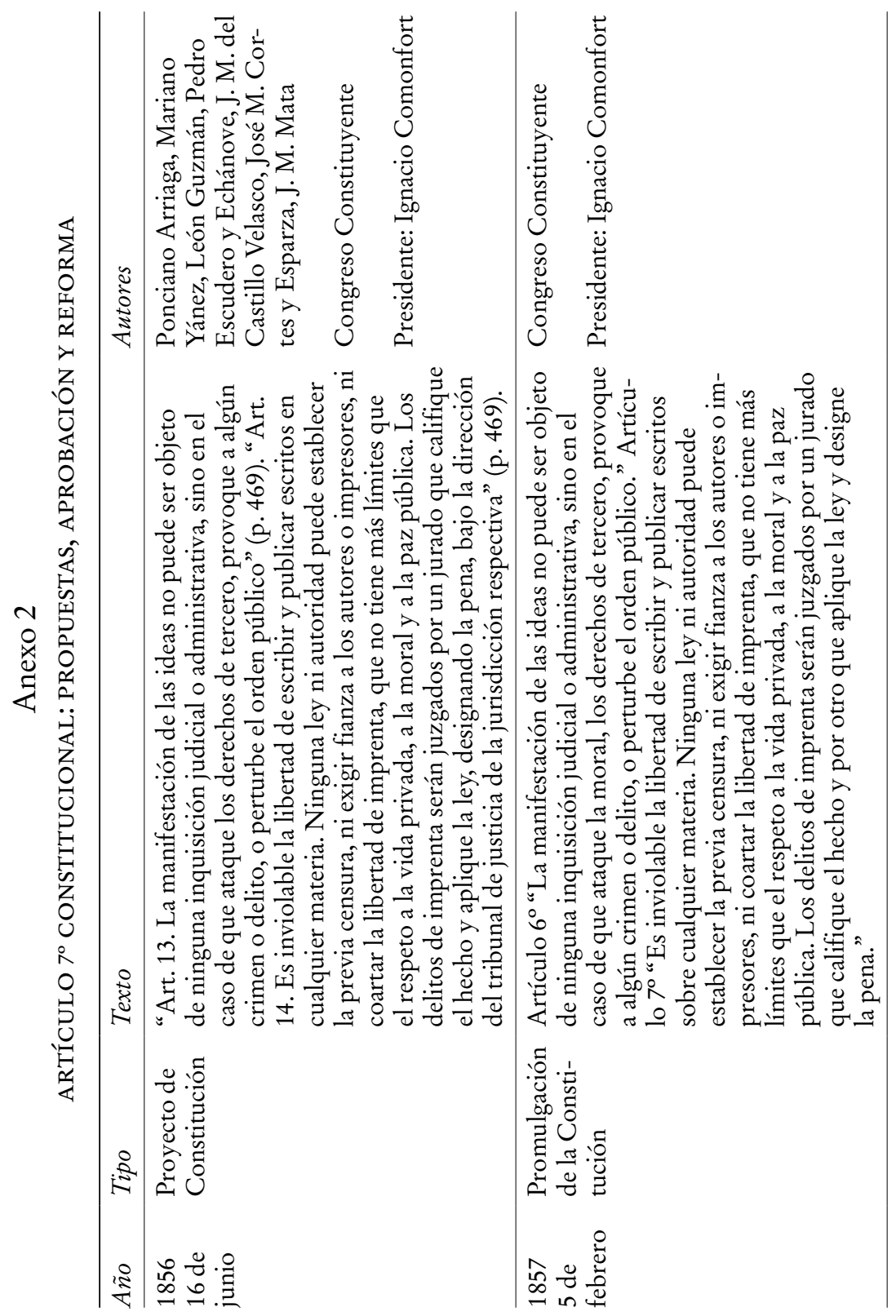




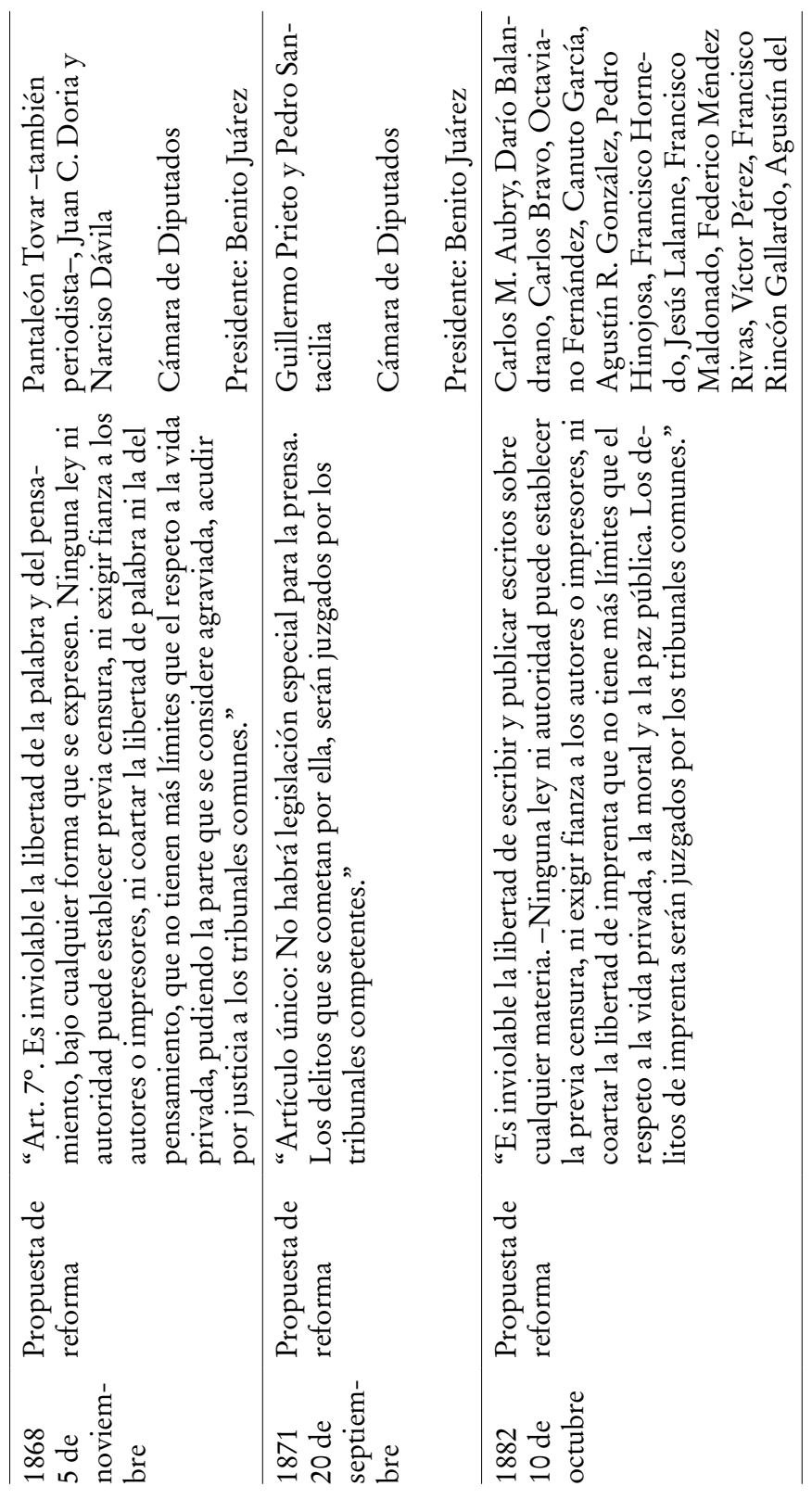




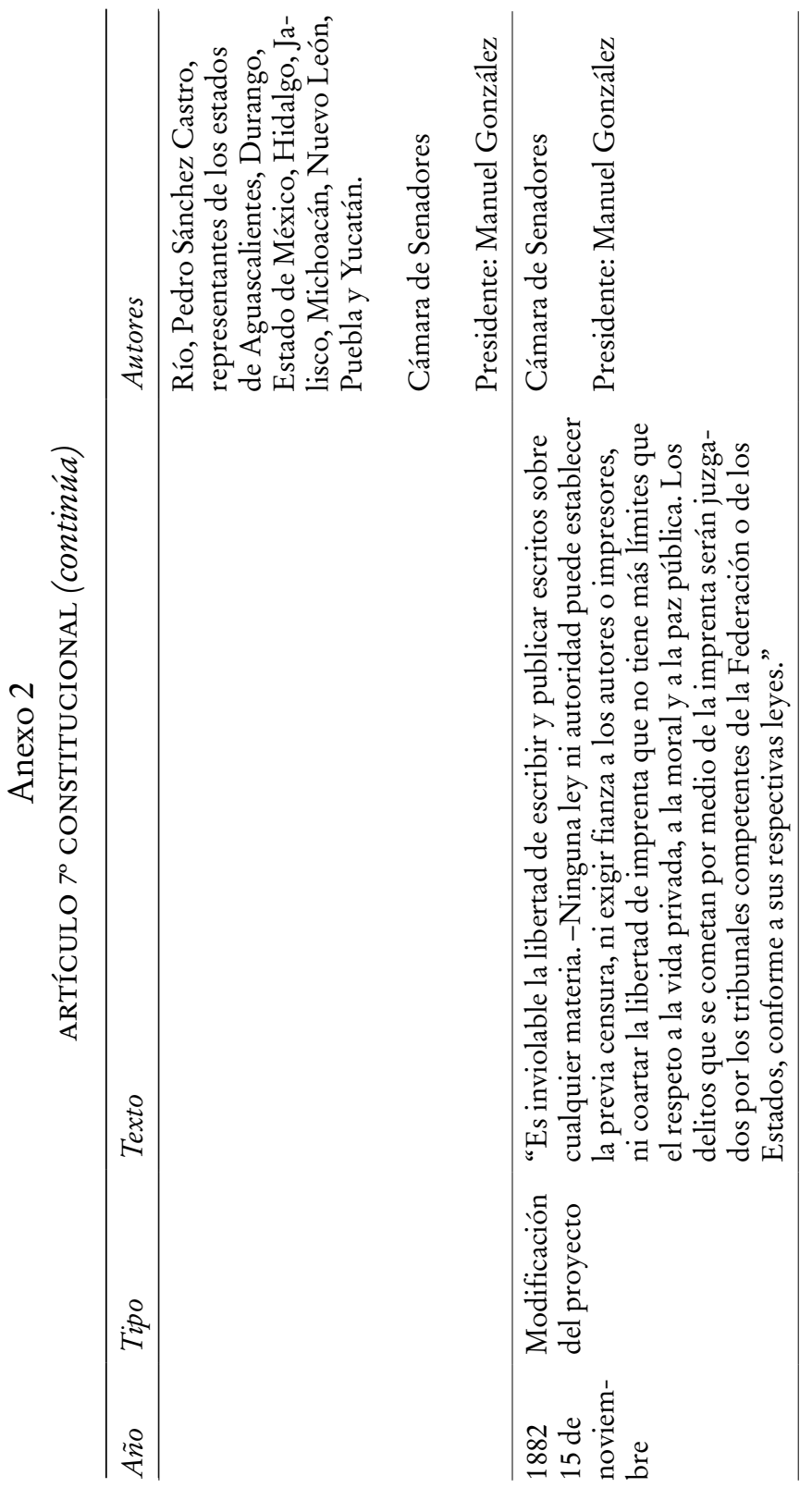




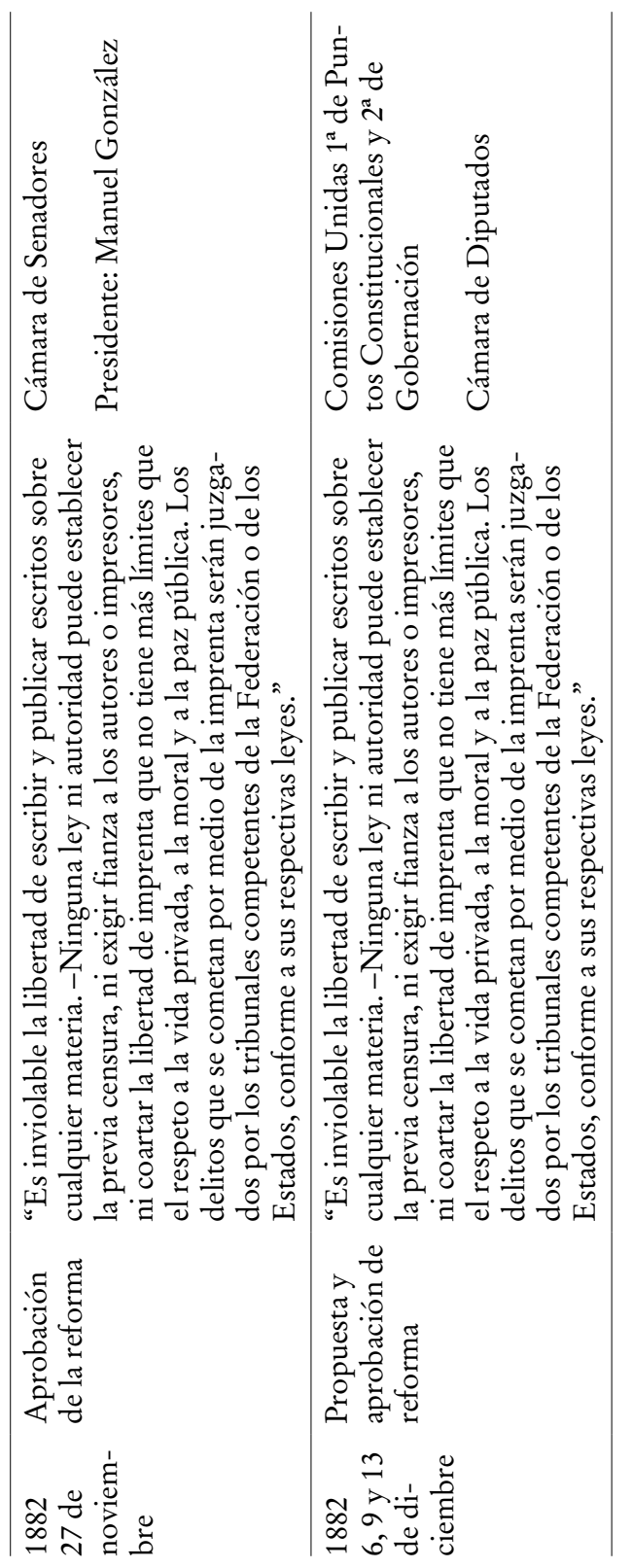




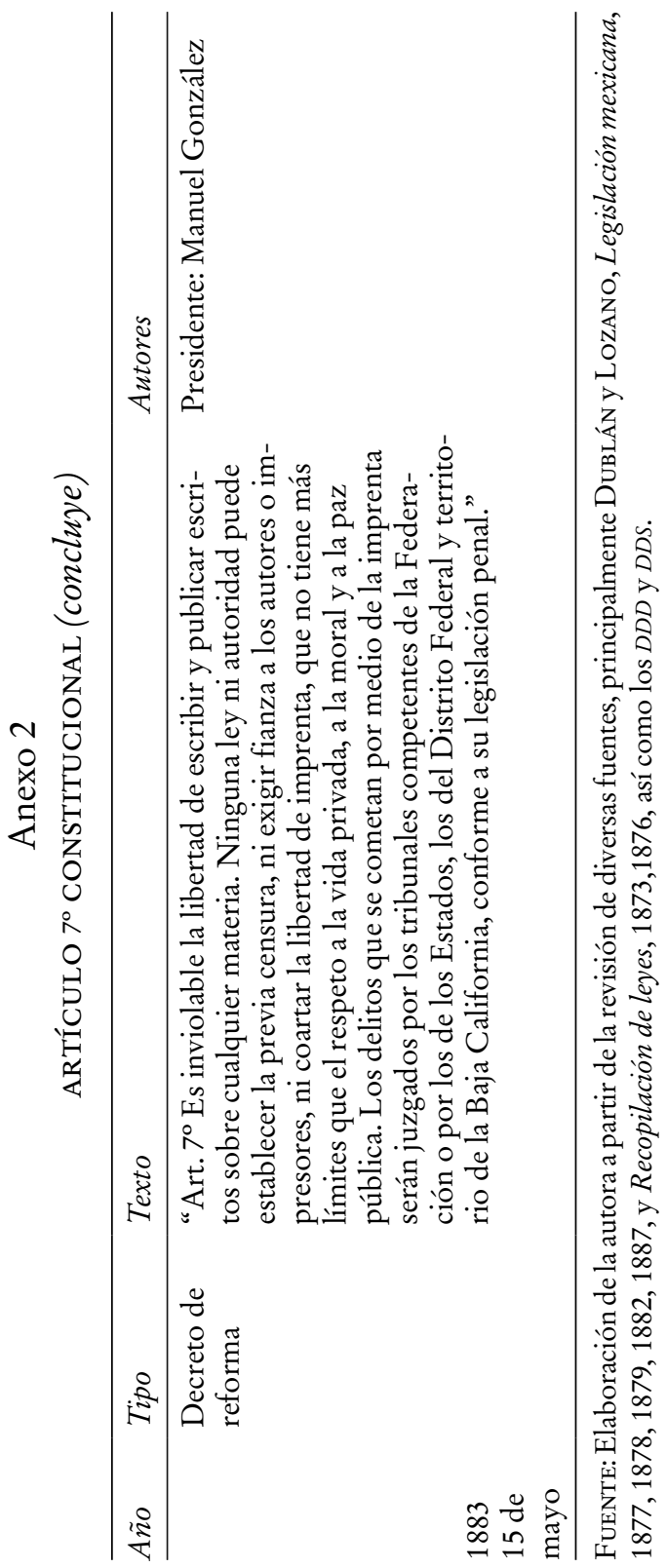




\section{SIGLAS Y REFERENCIAS}

DDD Diario de los Debates de la Cámara de Diputados, 1868, 1871, $1879,1882$.

DDS Diario de los Debates de la Cámara de Senadores, 1882.

Aguilar Rivera, José Antonio, El manto liberal. Los poderes de emergencia en México, 1821-1876, México, Universidad Nacional Autónoma de México, 2001.

Arenal Fenochio, Jaime del, "Juárez: uso y abuso de las facultades extraordinarias”, en Josefina Vázquez (coord.), Juárez, historia y mito, México, El Colegio de México, 2010, pp. 163-176.

Chávez Lomelí, Elba, Lo público y lo privado en los impresos decimonónicos. Libertad de imprenta (1810-1882), México, Miguel Ángel Porrúa, 2009.

Constitución Federal de los Estados Unidos Mexicanos de 1857.

COUDART, Laurence, “La regulación de la libertad de prensa (1863-1867)”, en Historia Mexicana, LXv: 2 (258) (oct.-dic. 2015), pp. 629-687.

Dublán, Manuel y José María Lozano, Legislación mexicana o Colección completa de las disposiciones legislativas, México, Imprenta del Comercio, ts. VII: 1877; VIII: 1877; IX: 1878; X: 1873; XI: 1879; XII: 1882; XIII: 1886; XVI: 1887.

Ferreiro Galguera, Juan "Libertad de imprenta en México: hacia una ley federal de comunicación social", en Anuario da Facultade de Dereito da Universidade da Coruña, 5 (2001), pp. 289-314.

GanTús, Fausta, Caricatura y poder político. Crítica, censura y represión en la cindad de México, 1876-1888, México, El Colegio de México, Instituto Mora, 2009.

GANTÚs, Fausta, “¿Gobierno represor o 'prensa infame’? Un vistazo a la caricatura de La Actualidad, ciudad de México, 1885-1886”, en Poupeney Hart, Navarro y Bastin (dirs.), pp. 245-275.

Gómez de Lara, Fernando, Manuel González Oropeza, David M. Vega Vera y Javier Zenteno Barrios, Estudios sobre la libertad de prensa en México, México, Universidad Nacional Autónoma de México, Corte Constitucional de Guatemala, 1997. 
Martínez Báez, Antonio y Felipe Tena Ramírez, Suspensión de garantías y legislación de emergencia. Concepto general del estado de sitio. Las facultades extraordinarias en el Derecho mexicano, México, Universidad Nacional Autónoma de México, 2006.

Poupeney Hart, Catherine, Aura Navarro, Georges Bastin, Ilustrar la nación. La prensa temprana en el mundo atlántico, París, Editions Le Manuscrit, 2014.

Recopilación de leyes, decretos y providencias de los poderes legislativo y ejecutivo de la Unión. Formada por la redacción del "Diario Oficial", México, Imprenta del Gobierno en Palacio, a cargo de José María Sandoval, ts. XIV: 1873; XVI: 1873; XXIV: 1876.

Salmerón, Alicia y Fernando Aguayo (coords.), "Instantáneas" de la Ciudad de México. Un álbum de 1883-1884, México, Instituto Mora, Universidad Autónoma Metropolitana-Cuajimalpa, t: I, 2013.

SPeckman Guerra, Elisa, "Justicia, política y honor: La supresión del jurado de imprenta en el Distrio Federal”, en SAlmerón y AguaYo (coords.), 2013, pp. 197-210.

Vallarta, Ignacio, Cuestiones Constitucionales. Votos como Presidente de la Suprema Corte de Justicia, México, Imprenta de Francisco Díaz de León, t. III: 1882; t. IV: 1883. 